Policy Research Working Paper 2614

South-South Regional Integration and Industrial Growth

\section{The Case of the Andean Pact}

Dorsati H. Madani
Results from this study of

three Andean countries cast doubt on the argument that countries may benefit from regional integration arrangements because of industry and cross-industry effects of scale. Unilateral Iiberalization might have a more positive impact on output growth, through the channel of greater imports of intermediate inputs.

The World Bank

Development Research Group

Trade

June 2001 


\section{Summary findings}

Has the revival of the Andean Pact affected the industrial growth of Bolivia, Colombia, and Ecuador? Has this regional agreement had greater effects than unilateral liberalization?

Madani explores two potential channels for industrial growth: scale effects and variety of imported intermediate inputs.

She analyzes data from 22 industries (classified at the three-digit level of ISIC) across three countries. The results show that:

- The variety of intermediate inputs originating from nonregional partners has a significant positive impact on growth in a handful of industries.
- The effect of regional variety is at best mixed. This lends preliminary support to the argument that unilateral liberalization will have a positive impact on output growth through the channel of imported intermediate inputs.

There is significant heterogeneity in industry-level returns to scale. Moreover, in the three Andean countries studied, cross-industry scale effects were small and negative. Therefore, the three countries should not expect large or across-the-board gains through scale effects from their regional arrangement.

This paper-a product of Trade, Development Research Group-is part of a larger effort in the group to understand the effects of regional integration. The study was funded by the Bank's Research Support Budget under the research project "The Impact of the Revival of the Andean Pact and the ASEAN Group on Their Member Countries' Industrial Growth." Copies of the paper are available free from the World Bank, $1818 \mathrm{H}$ Street NW, Washington, DC 20433. Please contact Robert Simms, room MC3-322, telephone 202-473-7156, fax 202-522-1159, email address rsimms@worldbank.org. Policy Research Working Papers are also posted on the Web at http://econ.worldbank.org. The author may be contacted at dmadani@worldbank.org. June 2001. (52 pages)

The Policy Research Working Paper Series disseminates the findings of work in progress to encourage the exchange of ideas about development issues. An objective of the series is to get the findings out quickly, even if the presentations are less than fully polished. The papers carry the names of the authors and should be cited accordingly. The findings, interpretations, and conclusions expressed in this paper are entirely those of the authors. They do not necessarily represent the view of the World Bank, its Executive Directors, or the countries they represent. 


\title{
South-South Regional Integration and Industrial Growth: The Case of the Andean Pact*
}

\author{
Dorsati H. Madani \\ Dmadani@worldbank.org
}

PREM-EP Trade

JEL: F14, F15, O4

* This paper is part of a research project (RPO-682-43) funded by the World Bank Research Group. All opinions expressed are solely those of the author. I greatly benefited from discussions with Alan Winters, Maurice Schiff, Maria-Soledad Martinez Peria, Isidro Soloaga, Simon Evenett, Marcelo Olarreaga, David Tart, Aart Kraay and Tony Venables. I would also like to thank participants at the World Bank Research Group Trade Seminar Series, Midwest International Economics meetings (Purdue University, Indiana), and the European Trade Study Group (Amsterdam) for comments and suggestions. 



\section{Introduction}

The late-1980s and early 1990s have witnessed a renewed interest in regional integration in both the academic and policy realms. The further integration of the European community and the creation of NAFTA have fanned this interest. Fear of losing access to these markets has prompted some developing countries to form such schemes, strengthen old agreements or investigate the potential for one. A few examples include Mercosur ${ }^{1}$, the Andean Pact, $\mathrm{CACM}^{2}$ and $\mathrm{ASEAN}^{3,4}$. A major question that has arisen from these pursuits is whether a regional arrangement has growth effects that are significant enough to warrant a developing country joining such a scheme.

This research proposes to answer a more specific question: how does adherence to a regional arrangement affect a developing country's industrial growth? I use two mechanisms to capture this impact: economies of scale and increased variety of intermediate imports. In the presence of scale economies, the literature predicts that gains from specialization and agglomeration associated with regionalism and integration will be enhanced. Caballero and Lyons $(1990,1992)$ find no support for within industry scale, but rather a strong cross-industry scale effect for a sample of developed countries. The authors argue that their "results suggest that the opportunities for unexploited increasing returns in manufacturing are much less widespread than the [European] Commission's (1988a) analysis concludes (1990:824)".5.

\footnotetext{
'Created in 1991 by Argentina, Brazil, Uruguay and Paraguay. Chile and Bolivia became associates in 1996.

2 Central American Common Market (CACM) was founded in 1960 by Nicaragua, El Salvador, Costa Rica, Honduras and Guatemala and revived in the early 1990s with a strong trade impact. The Andean Pact consists of Bolivia. Chile (left in 1976), Colombia, Ecuador, Peru and Venezuela and was established in 1969. It was revised and reinvigorated in the late 1980 s with reported strong impact on the level and intensity of its internal trade.

${ }^{3}$ ASEAN was established in 1967 by Indonesia, Malaysia, Singapore, Thailand and Philippines (Brunei joined in 1984 and Vietnam in 1995) as more of an agreement to foster peace and cooperation in the region than promote trade. The nonpriority of trade relations is clear from the little impact the agreement has had on intra-regional trade.

${ }^{4}$ For more details on these regional agreements, refer to F. Fouroutan 's March 1998 "does Membership in an FTA Make a Country more or less Protectionist?", WPS \#1898, DEC/RG, World Bank.

5 All the authors of the three chapters dedicated to the analysis of the potential gains from economies of scale in EC 1988 publication Research on The Cost of Non-Europe, Basic Findings, Volume 2 agree that European integration will lead to a definite exploitation of economies of scale (EOS). For instance, C. Pratten argues that "there are substantial scale effects for products and production runs to be obtained in a wide range of manufacturing industries" (pg. 162). J. Schwalbach presents estimates of changes in plant sizes and cost improvements due to increased trade for U.K. and Germany for the years 1965 and 1982 . He finds that for Germany, "trade flows (during the period 1965-1982) basically doubled plant sizes within the observed time period" (pg. 192). He also reports that plant size improved cost efficiency.
} 
Intermediate imports can affect growth by being conduits of technological knowledge across two countries. I test whether increased variety of intermediate imports, realized through liberalization of trade, has a growth impact. Two import variety measures are used to test this proposition.

I incorporate the two mechanisms of the regional effects using an expanded growth accounting methodology. The analysis focuses on industry level ( 3 digit ISIC) data for three Andean Pact countries over 16 to 23 years. To our knowledge, no dis-aggregated analysis of the impact of regional arrangements has been done for developing countries and specifically for the Andean Pact.

The results provide new insight into the industrial structure of three developing economies. The three Andean Countries in our study have very small, negative external economies. These results are in line with work by Basu and Fernald (1995) and reject the argument proposed by Caballero and Lyons $(1990,1992)$ that large positive externalities exist at the manufacturing level. We also find that there is significant heterogeneity in industry scale effect, in line with work by Burnside (1996). Therefore, not all industries would benefit from the potential scale effect engendered by regional integration. These results provide empirical support from developing economies on analysis thus far undertaken largely on developed countries manufacturing sectors ${ }^{6}$.

Regarding the role of imports, namely intermediate imports, the results show that the non-regional (ROW) suppliers and goods variety have a positive, small and significant effect for a handful of industries. The corresponding regional measures bring out a more mixed picture. They seem to have very little positive impact on output growth. Finally, we could not validate that the regional revival vs. unilateral liberalization had an impact on industry and cross-industry scales.

The implications of these findings are two folds. First, I find preliminary and weak support that unilateral liberalization will have a positive impact on industry level output growth via the channel of imported intermediate inputs. Second, given the heterogeneity of the industry scale effects and the very small cross-industry externality, the countries in this study should not expect large or across the board gains from their regional arrangement via scale effects.

\footnotetext{
${ }^{6}$ One recent exception is the article by Feenstra, et. al. (1999). "Testing Endogenous Growth in South Korea and Taiwan", Journal of Development Economics, Vol. 60.
} 
This paper is structured as follows. Section II reviews the literature while section III contains a brief overview of the developments in the Andean Pact. Section IV lays out the theoretical construct of the exercise. Section V provides the empirical analysis. Section VI concludes.

\section{Literature Review}

The literature lays out several avenues through which integration can affect growth. The more traditional approach credits integration with expanding markets and therefore providing the domestic industries who are confined by the size of their national market an opportunity to gain from internal economies of scale. This would improve production efficiency and engender growth. Industries may also benefit from the agglomeration resulting from the integration process. Finally, integration may influence industries via cross-industry externalities.

The endogenous growth theory argues that benefits accrue to an industry and an economy through the economies of scale engendered by increased "trade knowledge". Trade knowledge includes and can be modeled as gains from foreign R\&D embodied in traded goods, technology transfer through trade or foreign direct investment, process innovation, best practice implementation, and imported intermediate goods variety and quality. Furthermore, domestic human capital stock is built up due to exposure to new and more sophisticated intermediate and final goods (learning by doing, copying, ${ }^{7}$.

The literature has attempted to capture the growth effects of a regional integration agreement (RIA) in a variety of methods. They include theoretical modeling, simulation exercises, and empirical analysis (econometric evaluations). Baldwin and Venables (B\&V, 1995) provide a succinct and valuable survey of this literature. While both theoretical and simulation exercises provide invaluable insight into the topic, this research will pursue a disaggregated empirical (econometric) approach. This is because the issue at hand can ultimately only be settled through empirical analysis. However, according to B\&V (1995) this aspect of the analysis is far from mature ${ }^{8}$.

7 For a sample of recent works in this area see Baldwin and Seghezza, 1996; Coe and Helpman, 1995; Ben-David, 1994, 1995, 1996.

${ }^{8}$ According to $\mathrm{B} \& \mathrm{~V}$, the empirical analysis in this area is "...far from mature, ... but tentatively suggests that some RIAs have had a positive impact on growth, at least in Europe (1995:1627-28)". 
The empirical studies are typically based on Solow's neo-classical growth model. They assume perfect competition and constant returns to scale. They use a variety of independent variables and focus on the analysis of aggregate cross-country data or aggregate time series data for a single country. Most authors have attempted to integrate the impact of RIA using dummy variables (Brada \& Mendez, 1988; Casella, 1996) or a measure of inter and intra- regional trade volumes and flows amongst member countries (Italianer, 1994; Caceres, 1994). Some have attempted to incorporate the dynamic effect of integration by using investment series (De Melo, et. al., 1993) and human capital (Henrekson, et.al, 1996). Most studies use the EC as an empirical example?

An exception to this trend is the 1988 study by Brada and Mendez ${ }^{10}$ in which they find very small growth effects and conclude that while RIA dynamic effects exist, they play an insignificant role on the growth rate of member country outputs. A more recent work by De Melo, et. al. (1992) supports the same conclusion ${ }^{11}$. De Melo, et. al. (1993) attempt to capture the dynamic effects of regional integration on growth by incorporating human capital and investment. They find that the former only contributes significantly to growth in developing nations. Investment has significant dynamic effect on growth across all countries while adherence to a regional arrangement does not impact long term growth ${ }^{12}$.

${ }^{9}$ Henrekson et. al. (1996) also includes EFTA.

${ }^{10}$ Their study spans 1951-77 and estimates the dynamic effects of six RIAs, including 3 in developing countries (CACM, LAFTA and EACM). Their country level analysis finds that for five out of six Regional integration agreements' investment levels had increased. In two out of six agreements, technological progress had occurred as well. However, overall, they find very small growth effects of these agreements. "The largest gain was achieved by the member countries of LAFTA for whom these dynamic effects, cumulated over the period 1960-1977, resulted in 1977 GNPs 1.09\% higher than they would have been without integration (1988:163)". They conclude that while there are dynamic effects from regional agreements, they play an insignificant role on the growth rate of member country outputs.

${ }^{11}$ Their study includes a cross-sectional aggregate analysis of seven regional agreements, including four developing countries' (SACU, LAFTA, CACM and CEAO). Their study spans 1960-1985 and includes 23 developed and 78 developing nations. They use dummy variables in a basic neo-classical growth model to represent adherence to different RIAs and conclude that such a membership does not significantly impact growth.

${ }^{12}$ The authors do point out that the statisical insignificance of RIA dummies' may be related to their correlation with other regressors (investment). In fact they find that investment rates in the EC and especially EFTA was some five- percent higher than in other developed countries. This would suggest a degree of dynamic effect of RIA on growth. They find no support for the inclusion of economies of scale. 


\section{Why the Andean Pact? ${ }^{13}$}

The Andean Pact, established by the Cartagena agreement in 1969 by Bolivia, Colombia, Ecuador, Peru, Chile and Venezuela ${ }^{14}$, was created with a common market goal in mind. It's earlier mandate emphasized economic cooperation in the guise of trade liberalization, investment and industrialization policies for the region ${ }^{15}$. By the late $1980 \mathrm{~s}$, it had known periods of relatively small success of promoting internal tariff reduction and intra-regional trade growth. The small success is mainly attributed to two factors. One is the $1980 \mathrm{~s}$ debt crisis. The other reason lay in the original Andean Pact agreement. This latter blended regional industrial planning and concessionary measures, which created enough exceptions as to minimize the impact of the RIA to a small trade effect. According to Echevarria (1998), regional trade constituted less than two percent of total trade at the time.

The Declaration of Ica in $1989^{16}$ initiated the revival of the Pact and free trade was established in 1991. Since then the Andean Pact trade, patterns have altered dramatically (Yeats, 1998; Echavarria, 1998). The three countries in this study (Bolivia, Ecuador and Colombia) show a noted and rapid increase in their total and relative industrial imports from regional partners, see Graphs 1-6. Echavarria (1998) notes the same phenomenon on the export side. In fact, these exports to regional partners grew 5 times faster than manufactured exports to the world.

All members of the Pact also implemented extensive unilateral liberalization almost simultaneously with this regional revival. Bolivia, the early reformer, started its program in the mid-1980s and by 1992, its weighted average ad-valorem tariff rate was nine percent, a reduction of more than $50 \%$ compared to 1986 . Colombia cut its weighted average ad-valorem tariff rate from $45 \%$ in 1988 to $21 \%$ in 1990 and to $11 \%$ by 1992 . Venezuela reduced its ad-varolem tariff rate from $26 \%$ in 1988 to $12 \%$ in 1992 and Ecuador's rates went from $29 \%$ to $10 \%$ between 1990-92. Furthermore, most non-tariff barriers were eliminated in the region by 1991: their coverage was zero percent in Bolivia and Ecuador in 1991-1992, one percent in Colombia and five percent in Venezuela (Echavarria, 1998; Edwards, 1995).

\footnotetext{
13 See Appendix for country specific information.

14 Chile was a member but withdrew in 1976.

15 It also provided concessionary measures for its less developed members such as Bolivia and Ecuador.

16 One such instance of intra-regional trade growth was during the late 70 s and before the debt crisis.
} 
The evolution of the Andean Pact has registered a noted effect on its members' trade pattern. More specifically, its vigorous revival in the early $1990 \mathrm{~s}$, has led to increased manufacturing goods exports to (and imports from) regional partners. We anticipate that by extension their industrial growth should be affected by this reorientation. The simultaneous unilateral liberalization of its members has created an interesting backdrop for us to test the theoretical implications of the literature on regionalism and growth.

\section{Theoretical Base and Applications}

The early theoretical and empirical analysis of growth is based on the assumption of perfect competition and constant returns to scales and uses a general production function, $Y_{1}=A \cdot f\left(K_{1}, L_{1}, M_{1}\right) . \quad A$ is the index of Hicks-neutral technological progress, and $f($.$) is a$ continuous, twice differentiable function that is homogeneous of degree one in capital $\left(K_{t}\right)$, labor $\left(L_{1}\right)$ and material $\left(M_{t}\right)$. We differentiate $Y_{t}$ and manipulate the resulting expression to obtain equation (1).

$$
d y_{1}=s_{l t} d l_{t}+s_{k t} d k_{t}+s_{m t} d m_{t}+d a_{t} \quad \text { or }
$$

$$
d y_{1}=d x_{t}+d a_{t}
$$

where $d x_{t}=s_{l l} d l,+s_{k l} d k_{1}+s_{m l} d m_{1}$,

$d y_{1}=\ln \left(Y_{t}\right)-\ln \left(Y_{t-1}\right) ; d l_{t}=\ln \left(L_{t}\right)-\ln \left(L_{t-1}\right) ; d k_{t}=\ln \left(K_{t}\right)-\ln \left(K_{t-1}\right) ; d a_{t}=\ln \left(A_{t}\right)-\ln \left(A_{t-1}\right)$ and $d m_{t}=\ln \left(M_{l}\right)-\ln \left(M_{t-1}\right) . s_{l}, s_{k}, s_{m}$ are average (over two periods $\mathrm{t}$ and $\mathrm{t}-1$ ) of shares of labor, capital and material in total gross output respectively ${ }^{17}$. Equation (1) states that output growth is a function of changes of weighted shares in factors and inputs plus total factor productivity (henceforth TFP). The latter reflecting the exogenous, "unexplained" element of growth.

\footnotetext{
${ }^{17}$ The literature favors the use of cost shares instead of revenue shares (Hall, 1990; Basu and Fernald, 1996). In the presence of imperfect competition, revenue shares may lead to potential mis-measurement in the contribution of factors to growth ${ }^{17}$. However, we do not have the necessary data for such calculations. We proceed with revenue shares, heeding the fact that our calculations include potential calculation bias.
} 


\section{A. Accounting for Economies of Scale}

Subsequent work within the growth framework by Caballero and Lyons $(1990,1992)$ and Basu and Fernald (1996) and Burnside (1996) extend the work by Solow (1956) and Hall (1988, 1990) to investigate the presence of scale effects versus (cross industry) external economies of scale.

We apply Caballero and Lyons methodology to industry level data of the three Andean Pact countries (Appendix 1 lays out their model more fully). We analyze the impact of regional integration on industry growth for three Andean Pact countries in light of scale effects and (cross-industry) external economies of scale. This is to investigate the general claim made in the integration literature that, in the presence of externalities, the impact of such arrangements is several fold larger ${ }^{18}$.

Caballero and Lyons point out that in estimating industry level growth (equation (2) below) we need to take into account the fact that the industry level $(I)$ and aggregate level inputs ( $x_{i t}$ and $x_{t}$ ) will be positively correlated. In the presence of external effects (cross-industry externality), therefore, the estimated coefficient in equation (2), will be upward biased ${ }^{19}$. They model external effects as $x_{t}=\sum_{i} x_{i}$ and its coefficient, $\kappa=\frac{\beta \gamma}{1-\beta}$ in equation (3). $K$ is expected to carry a positive value and capture the impact of cross-industry externality on industry $\mathrm{i}$.

The error term $\left(\xi a_{1}+u_{i l}\right)$ is unobservable here ${ }^{20}$.

$$
d y_{i t}=\gamma d x_{i t}+\left(e_{i t}+d a_{i t}\right)
$$

$$
d y_{i t}=\gamma d x_{i t}+\kappa d x_{t}+\left(\xi d a_{1}+u_{i t}\right)
$$

18 Specifically, existence of cross-industry externality should benefit member nations for it increases production efficiency. Also, if there is industry scale effect then, as suggested by the theoretical and simulation literature, developing countries adhering to an RIA could experience large benefits

${ }^{19}$ In the presence of external effects, therefore, the estimated coefficient in equation (2), called $\theta$ from now on, will be upward biased. In fact, according to C\&B (1990),

$$
\operatorname{plim} \theta=\gamma+\psi \kappa, \text { where } \psi=\frac{\sigma_{d x}, d x_{i}}{\sigma_{d x_{i}}^{2}} .
$$

${ }^{20}$ Note that $\xi=\frac{1}{1-\beta}$. 
where $x_{i t}=\alpha_{1 i t} l_{i t}+\alpha_{2 i t} k_{i t}+\alpha_{3 i t} m_{i t}$ and $\alpha_{i t l}, \alpha_{i t k}, \alpha_{m i}$ are shares of labor, capital and materials in industry $I . \gamma$ represents economies of scale (here, and for the moment, we constrain $\gamma$ to be the same for all industries) $a_{i t}$ productivity $(T F P)$ index and $e_{i t}$ represents the external economy (cross-industry) index. Both are assumed to be unobservable in equation (2) and therefore part of the error term.

We will concentrate on the estimation of equation (3).

\section{B. Introducing measures of integration}

We use three measures to capture the potential impact of the revival of the RIA. The first two measures are constructed with the understanding that trade is an essential conduit of the impact of integration on growth ${ }^{21}$ and that increased variety of intermediate imports plays an important role in output growth. The use of these two alternative measures is to better gauge the sensitivity and accuracy of our results. The third measure is the prevalent approach in the literature (Casella, 1996; De Melo, et. al., 1993): a dummy variable, which takes on a value of one starting in 1991.

\section{B2. Import Variety Measures.}

How would increased intermediate imports initiate a within and cross-industry scale response? Compared to an autarkic anti-monde, implementation of an RIA will increase availability of differentiated intermediate inputs ${ }^{22}$, which leads to a scale effect and increased industrial growth ${ }^{23}$. More specifically, we view the new varieties of intermediate imports as stores of foreign knowledge. We conceptualize that they have a strong industry specific knowledge accumulation component, and a more diffuse overall/general knowledge

21 This, of course, is not a new idea. The endogenous growth literature has used the trade conduit as a modeling tool. See Ben-David (various papers) and Coe and Helpman (1996) for examples.

22 The South-South RIA of the Andean Pact can be likened to the Grossman \& Helpman narrow gap imitation scenario (chp 11, pg. 294-298). They assume a North-South framework, with the former innovating and the latter imitating (and potentially innovating less intensively). The narrow gap refers to the fact that the gap in manufacturing costs between North and South is not wide.

23 See appendix for the outline of the new growth model. 
component ${ }^{24}$. They affect the knowledge base in the importing country in the following two complementary manners. At the cross-industry level, they enlarge the general, public base of knowledge, providing further incentives for innovation by reducing innovation costs across all industries. Also, availability of new varieties of intermediate improves production efficiency and lowers input costs in industries using them for production of final goods ${ }^{25}$.

In practice, of course, we do not have a purely autarkic empirical anti-monde for none of the RIA members in this study has been entirely excluded from the world trading system in the 1970-1995 period. Rather we have a situation where countries make a graduated move from more restrictive trade practices to less restrictive (but possibly more distorted) ones. Thus, our experiment is essentially of whether the changes entailed in the RIAs have increased the net supply (quantity and quality) of intermediates. We control for the potential impact of unilateral liberalization by introducing import variety measures calculated for non-RIA member suppliers into our analysis. This allows us to simultaneously gain some insight into the impact of unilateral liberalization on these countries ${ }^{26}$.

We construct alternative indices of variety that capture the shocks of new imported intermediate inputs. They can be formulated using available three digit ISIC or four digit SITC data over individual supplier countries or blocks of supplier countries, see below. The two indices for variety considered here are: first date of imports as measured by the number of suppliers and first date of imports as measured by an index of goods variety. Below we provide details about these measures.

${ }^{24}$ Another way of modeling this dichotomy in the knowledge accumulation is to argue that the human capital is so specialized and productive in the set -up of the specific industry it is working in that it will "extract" more knowledge from its industry specific imports than the rest of the industries could. Alternatively, we could argue The human capital is differentiated by industry and therefore is less productive when having to absorb (or invent) in a general arena versus its own specific industry.

${ }^{25}$ We do not directly model the prerequisites for an agglomeration outcome since it requires cross-country factor movements (which we abstract from in our basic model in Appendix 1) and involves the more detailed analysis of centripetal and centrifugal economic forces between the integrating (see also Puga and Venables, 1997; Ruhashyankiko 1997). Therefore, we abstract from arguing that within industry externalities are directly correlated to agglomeration effects resulting from the RIA We still attribute these externalities to the increased variety of intermediate inputs.

26 Variety trade diversion can increase the regional varieties as the expense of larger numbers of varieties from the rest of the world. This may be especially relevant if the regional grouping is not variety rich. 


\section{a. Goods Variety}

We construct a variety measure described in Feenstra and Markusen (1994). Starting out with a single, competitive firm with constant returns to scale, and assuming a CES production function:

(4) $Y=f(x, N)=\left[\sum_{i=1}^{N} a_{i} x_{i i}^{\theta}\right], \quad 0<\theta<1$,

where $x$ is the quantity of inputs $i=1, \ldots, N$ and $x=\left(x_{1}, \ldots, x_{N}\right)$ denotes the vector of inputs, and $Y$ is the output. The elasticity of substitution between the inputs is given by $\sigma=1 /((1-\theta)$. $P_{i}>0$ is the price of inputs and assume that $x_{i}>0$ solves the cost minimization problem of the firm.

Assuming two ranges of inputs $N_{s} \leq N_{t}$, Feenstra and Markusen (1994) show that:

(5) $f\left(x, N_{1}\right)=f\left(x, N_{s}\right) \lambda^{(1 / \theta)}$, where $\lambda=\left[\frac{\sum_{i=1}^{N_{i}} p_{i} x_{i}}{\sum_{i=1}^{N_{s}} p_{i} x_{i}}\right]$ and $\lambda^{(1 / \theta)} \geq 1$.

The outputs obtained with the ranges of inputs at times $\mathrm{s}$ (denoted $N_{s}$ ) and $\mathrm{t}$ (denoted $N_{1}$ ), $\left(N_{s} \leq N_{1}\right)$ are related by a "growth factor" $\lambda$ that is measurable as the ratio of expenditure on the full $\left(N_{t}\right)$ versus the restricted set $\left(N_{s}\right)$ of inputs ${ }^{27}$. As $\theta$ becomes smaller $\lambda$ increases because the new inputs become less substitutable for existing inputs, leading to larger increases in output.

Feenstra et. al.(1999) and Madani (1997) use a closely related methodology and highly dis-aggregated exports to the US to estimate the impact of relative industrial goods variety for Taiwan (China) and Korea on their industrial growth. For each industry $I$, changes in variety is captured by: 


$$
V A R_{i s t}=\ln \left(\frac{\sum_{n \in N_{t}} p_{n t} x_{n} / \sum_{n \in N} p_{n t} x_{n t}}{\sum_{n \in N_{s}} p_{n s} x_{n s} / \sum_{n \in N} p_{n s} x_{n w}}\right)
$$

Where $p_{m} x_{n t}$ is the value of input $x_{m}$ by industrial category $I$ from supplier $n$ at time $t$.

In our case, we consider the imported inputs variety and therefore, to interpret equation (6) above, consider the case where the set of imports is growing, and denote these sets by $G_{s}=\left\{1, \ldots, N_{s}\right\}$ and $G_{1}=\left\{1, \ldots ., N_{t}\right\}$ with $G_{t}>G_{s}$. Then the common set of imports supplied in both periods is $N=N_{s}$, and the denominator of the equation above is unity. The numerator will exceed unity, indicating that product variety has increased. This formula fits the case where goods disappear as well.

The variety measure is calculated for two subsets of importers: the members of the regional agreement (variable VARREG) and the non-members (rest of the world - called VARROW) and for each country's 22 3-digit industries over 26 years.

Estimation of equation (3) above is therefore altered to:

$$
d y_{i \prime}=\alpha_{1}+\gamma_{i} d x_{i \prime}+\kappa_{i} d x_{i}+\eta_{i} \operatorname{VARROW}(-1)+\theta_{i} \operatorname{VARREG}(-1)+\left[\xi d a_{1}+u_{i t}\right]
$$

Given the assumption of south-south RIA underlying our analysis (see appendix2) and the fact that these economies have relatively similar industrial structure (especially compared to developed countries), we expect very little regional variety effect. The assumption that ROW will have a larger variety of intermediate inputs to offer industries of RIA member countries leads us to expect unilateral liberalization to have a positive - and larger - impact on output growth than import of intermediate inputs from other RIA members.

There are two drawbacks to this method. First, we may not pick up too much variation in product variety due to the aggregate nature of the data ${ }^{28}$. Second, our data is on import values

\footnotetext{
${ }^{27}$ See proposition 1 of the Feenstra \& Markusen (1994) paper.

${ }^{28}$ We have constructed the 4 digit SITC version of this measure and will investigate this aggregation issue at a later date.
} 
in US dollars. We do not have complete data on unit values. Our numbers may therefore be biased by changes in import prices.

Clearly, imported goods are used as intermediate inputs in different industries and as final goods. Thus, using our variety measure, we could pick up several effects: a complementary effect of intermediate goods on industrial production; a competitive effect of these intermediate goods on the import competing industries; a competitive effects of imported final goods on domestic industrial production. In the two latter cases the negative correlation between increased imports and domestic industrial production springs from the rationalization of domestic industry faced with foreign competition. We are interested in the first effect: the complementary effect of intermediate imports.

Our series are scaled to isolate the complementary effects of regional vs. ROW suppliers of import variety on output growth from its competitive impact. We hypothesize that complementary imported varieties will have a positive impact on output. In other words this complementarity arises from the fact that these imported varieties are intermediate inputs feeding into - and improving - the production process of the domestic industries. This interpretation meshes in well with our theoretical model (appendix 2), where there is assumed substitution among intermediate inputs, but no redundancy.

Our trade data mirrors the same potential scrambling of signals/effects as above. The three digit ISIC-categorized imports are not all used by the industry associated with their category. Rather, they represent all imports into the country that match this type of industrial categorization. For instance, imports categorized as 311 (food products) are not all used in the Colombian food products industry. Rather, they are imports that matched the category 311 and will be distributed across the economy to be used as intermediate inputs or final goods.

We attempt to isolate the complementary effect by scaling our supplier and import variety measures with country specific input-output tables ${ }^{29}$. Our measures are weighted so that: (7) $w V A R_{i j t}=\sum_{i} v_{i j} V A R_{i s t}$

where $v_{i j}$ is obtained from the input-output table and is the share of inputs by industry $I$ into industry $J$. The scaled variety series used in industry $J$ therefore accounts for all potential variety changes from all its industrial suppliers.

${ }^{29} 1982$ input-output tables for Colombia, 1988 for Bolivia, 1986 for Ecuador. 


\section{b. First Date of Imports as Measured by the Number of Suppliers:}

We use this measure to pinpoint the date of first import from a foreign supplier. Assume Colombia is our importing country and its supplier is country $Z$. The available three digit ISICcategorized Colombian imports are differentiated by their supplier country. This will allow us to argue that first date of import from supplier country $Z$ represents launching a new variety of intermediate good in the Colombian industry. In consequent years, we register the entry or exit of suppliers. Tracking the change in the pool of suppliers over 1970-1994 for each industry provides a good proxy for the import variety available in the Colombian market before and after the RIA renewal ${ }^{30}$.

In this case, we hypothesize that against a backdrop of restrictive trade practices, adding a new supplier (a new variety of intermediate input) to the existing pool of suppliers will be interpreted as easing access into the Colombian market. Our measure of ROW suppliers (SUPLROW) captures the effects of unilateral liberalization. As in the case of our variety measure, since it allows for a larger variety of intermediate inputs, we expect a positive and significant coefficient. On the other hand, we expect little (or non-significant) variety effect from our regional analogue measure (SUPLREG) on industrial growth.

As in the case of the import variety measure, we scale our supplier measure with country specific input-output tables to isolate the complementary effect of intermediate input variety on industrial growth (see equation (8) above).

This variety measure has several shortcomings, including:

The first date of imports does not necessarily signify consistency of available imports from that source ${ }^{31}$. This would mean that we are over-emphasizing the impact of new inputs on growth.

This approach - assuming one variety from each country - may bias our results in two ways. First, this simplification will most likely lead to under-counting of the variety of imports

30 If the new imported goods are highly substitutable to the existing ones, the dynamic growth impact will not be large. If the new imported good is not very substitutable to the existing intermediate goods, its dynamic growth impact - AKA economies of scale - will be large;

${ }^{31}$ I have noted that in looking at imports from Andean Groups (especially) Bolivia. They tend to be erratic and sporadic in many instances. There seems be a degree of increased value and consistency in imports from Bolivia after 1989 in many of the 28 ISIC industries. 
provided by non-regional suppliers. For instance, large suppliers like the U.S. will likely supply multiple varieties of goods to a Colombian industry, whereas regional suppliers supply fewer varieties. Second, if there is trade diversion from world exports to RIA exports to Colombia, it will be registered as having a positive dynamic effect on industry level output growth even though the total number (variety) of intermediate inputs may not have changed or its quality component may have been reduced. Our measure is therefore biased in favor of RIA approach and against the unilateral liberalization policy approach.

\section{B2. The dummy variable.}

Our final measure of integration is the literature staple: a dummy variable that captures the 1991 renewal of the RIA. We define the dummy as:

$$
\begin{aligned}
& D=0 \text { up to } 1990 \\
& D=1 \quad 1991-1994^{32} .
\end{aligned}
$$

We introduce this dummy into the above Caballero and Lyons framework. Equation (3) above will now become the estimation equations:

$$
d y_{i t}=\alpha_{1}+\gamma d x_{i s}+\kappa d x_{1}+\tau_{i} d \text { Tariff }+\lambda D+\left[\xi d a_{i}+u_{i t}\right]
$$

where $\alpha$, is a constant; $x_{i t}=\alpha_{1 i l} l_{i t}+\alpha_{2 i r} k_{j t}+\alpha_{3 i t} m_{i t}{ }^{33}$ and $\left[\xi a_{i t}+u_{i t}\right]$ is the error term. The $\lambda D$ is an intercept dummy and will capture any shift in the overall level of growth. In the literature a positive and significant $\lambda$ is interpreted as a positive and significant impact of regional integration arrangement (RIA) on the industrial growth of a member country.

In effect, however, it is difficult to interpret accurately the coefficient on the dummy variable as the impact of the regional integration if we cannot isolate this impact from other simultaneously occurring economic events in the countries. The dummy may be picking up other influences such as world wide demand shock, productivity shock or major domestic policy (trade, macro or industrial) changes coinciding with the revival of the RIA. We control for the

\footnotetext{
${ }^{32}$ Note that for the Andean Pact this renewal is traced back to the Declaration of Ica in 1989, with free trade established in 1991. The RIA had a small impact up to the late 1980s. Also note that most cross-country (cross-sectional) macro analysis include a dummy for the launching of the RIA process. In our case (panel data) this is not possible since both agreements were formed before the starting date of our data.

33 by using the $x_{i t}$ terminology and not directly estimating the coefficients we lose information about the changes in the contribution of labor, material and capital to production. One interesting extension of this exercise would be to perform this analysis with estimated beta coefficients.
} 
simultaneous unilateral liberalization by including a proxy in our regressions: a country -specific time series ad-valorem tariff collection ${ }^{34}$.

\section{Data and methodology.}

The analysis is based on 22 industries $^{35}$ and concentrates on Bolivia (1977-1994), Ecuador (1974-1994) and Colombia ${ }^{36}$ (1973-1994). The 3-digit data on the countries' industrial gross output production, gross fixed capital, number of workers, wages and intermediate inputs were obtained from United Nations Industrial Development Organization database. The bilateral import data is from COMTRADE United Nations database (see appendix 3 for further information on the data).

For industry level analysis across the three countries of equation (3') and (3'), we rely on 3SLS methodology to account not only for the endogeneity of explanatory variables, but also for the potential contemporaneous cross industry correlation of the error terms. We also correct for heteroskedasticity. Here we assume that each of these industries have similar structure across the three countries. We tested for country specific characteristics. Inclusion of country dummies did not change the results of our analysis.

Equations ( $\left.3^{\prime}\right)$ and (3') were also estimated at the industry level for each country, using GMM Methodology ${ }^{37}$. This estimator provides more information by tapping the lagged level values as instrumental variables for the first differenced equation. Furthermore, the methodology allows for the general form of heteroskedasticity and autocorrelation providing more efficient

${ }^{34}$ The literature has used trade or import shares, recognizing their limitations and the endogeneity issues attached to such a use. The use of tariff ad-valorem collections or schedules is considered still considered problematic but an improvement on use of trade or import shares. Of course, the series we use is not a full proof proxy for liberalization. We could only obtain nationwide data on tariff. This measure therefore also captures the reduction in regional tariff rates as well.

35 We discarded coal and petroleum $(354,353)$, leather products $(323)$, other chemical industries (352), nonferrous metals (372), and pottery, china, etc...(361) for either severe data deficiencies or severe and implausible changes in data values.

${ }^{36}$ Venezuela lacked value added and intermediate input information and a full analysis could not be performed at present. We had to discard a study of Peru early on because of significant missing data problems.

37 Arellano and Bond (1991) and Arrellano and Bover (1995) have contributed to the development of this methodology for panel data. 
estimates $^{38}$. Using this methodology will give us standard errors (SE) that are robust to heteroskedasticity (White consistent SE) and auto-correlation.

Finally, we also modeled a cross-effect between the RIA measures and industry scale and cross-industry economies of scale ${ }^{39}$. In this case, equation ( $\left.3^{\prime}\right)$ becomes:

$$
\begin{aligned}
& d y_{i 1}=\alpha_{1}+\gamma d x_{i 1}+\kappa d x_{1}+\tau_{i 1} \text { REGVARmeasure }+\tau_{i 2} \text { ROWVARmeasure } \\
& +\mu_{n 1}\left(\text { REGVARmeasure } * x_{i t}\right)+\mu_{i 2}\left(\text { ROWVARmeasure } * d x_{i 1}\right) \\
& +\omega_{1}\left(\text { REGVARmeasure } * x_{1}\right)+\omega_{2}\left(\text { ROWVARmeasure } * d x_{i}\right) \\
& +\left[\xi_{a_{1}}+u_{i 1}\right]
\end{aligned}
$$

We interpret the $\mu_{i}$ and $\omega$ coefficients on the cross-effect terms as the impact of integration on economies of scale (both within and across-industries) and by extension on growth. Ceteris paribus ${ }^{4041}$, we expect the $\mu_{i} s$ and $\omega$ s to be positive and significant.

Throughout our analysis, we used our two alternative variety measures as well as the dummy variable specification ( seen in equation (3")).

We were mindful of potential heteroskedasticity problems that may arise in a panel data framework $^{42}$ and made the appropriate correction in our analysis.

Capital services may fluctuate as capacity utilization changes over the business cycle (Basu and Fernald, 1995; Burnside, Eichenbaum and Rebello, 1996). Since we have capital stock rather than an accurate measure of capital services we include a proxy to control for changes in

38 Griffiths, et. al. (1993), pg. 457 point to the fact that with the GMM, estimators are consistent, but not necessarily asymptotically efficient.

${ }^{39}$ Harrison (1994) uses a similar set up for her analysis of the impact of trade liberalization on firm behavior in Cote d'Ivoire.

${ }^{40}$ According to the literature, assuming the dummy is capturing an active regionalism effort, both $\mu_{i}$ and $\omega$ would be positive and significant: regionalism enhances industry scale economies through agglomeration and crossindustry externality through market expansion.

41 we are not comparing to unilateral liberalization.

${ }^{42}$ We used Breusch-Pagan heteroskedasticity tests to diagnose this problem. We also acknowledge that Judge et. al. (1985) warn about the weaknesses of such tests by pointing out that White's test significance may be indicating mis-specificiation (omitted variables or incorrect functional form) rather than heteroskedasticity. In our early IV analysis, our results were always heteroskedasticity corrected using the white method. The GMM takes into account a general form of heteroskedasticity. 
capacity utilization. Following precedence in the literature, we use country specific manufacturing level electricity utilization over the period 1971-1994 in both equations (3) and (6). Harisson (1994) uses a measure of total energy use while Burnside, Eichenbaum and Rebelo (1995) use electricity use as proxy ${ }^{43}$.

In order to avoid the effects of non-stationarity typically present in this type of data, we first differenced all the variables ${ }^{44}$. However, using first differenced variables is not without its shortcomings. We lose the cross-industry dimension of our data. Also, first differencing is criticized for a tendency to emphasize measurement errors (or noise) over signal. This decreases the signal to noise ratio and raises the possibility of poor precision in estimation.

An issue of serious concern is the endogeneity of some of the explanatory variables. The solution should be to instrument these variables. However, the use of this methodology has been questioned on two grounds. Hall (1998) highlights the first problem with using instruments: lack of truly exogeneous instruments that are highly correlated with the endogenous variable and not with the error term. Among the instruments Hall, the one with the highest correlation with the endogenous variables is the price of oil. It is also the most questionable instrument, because of the possibility that technical progress is not Hicks-neutral ${ }^{45}$. The second difficulty is that poorly fitting instrumental variables may lead to substantial small-sample bias ${ }^{46}$.

\footnotetext{
${ }^{43}$ They reference Griliches \& Jorgenson, 1967 and Costello, 1993 for precedence. Studying capacity utilization and returns to scale, they find constant returns to scale. They conclude that "their results strongly supports models which emphasize cyclical movements in capacity utilization rates as an important determinant of movements in conventional measures of total factor and labor productivity" (pp. 105).
}

${ }^{4+}$ This is a common practice in the literature. We tested for non-stationarity using the Dickey-Fuller test at the industry and country levels. We find that an overwhelming number of series have unit roots. We test for cointegration and find that again a large number of the relationships have unit roots and can't be used in levels.

We check for the presence of autocorrelation for the industry level data and find it present. In the presence of autocorrelation our LS coefficients will be unbiased but not efficient. The covariance matrix will be biased and the standard errors and consequent interval estimates and hypothesis tests will be invalid.

\footnotetext{
45 In her research on Cote d'Ivoire, Harrison (1994) argues that the OLS (fixed effects) and IV results are not qualitatively different. She bases her assessment on the Hausman test and the over-identification test results. Caballero and Lyons (1990) also point out that while Hall's concern about specification errors are warranted, the lack of good macro-instruments made the instrumental variable procedure powerless. They note that the reason for our concern over specification error is our interest in consistent parameter estimates. They argue that the inconsistency in coefficient estimates is small if the size of the variance of the regressors relative to their covariance with changes in productivity growth is small. In this case, there would be no need to give up on the least square approach $^{43}$

${ }^{46}$ Here Basu and Fernald (1995) refer to Nelson and Startz (1990).
} 
We attempted several alternative sets of instrumental variables based on the ones used by Harrison (1994), Hall (1988) and Burnside $(1996)^{47}$. We also tried the Anderson-Hsiao methodology: using one or more lagged log level of the endogenous variables as instruments for their corresponding first differenced values. Tests of over-identifying restrictions suggested that our instrument sets were generally valid ${ }^{48}$. That is there was no correlation between the instruments and the error term. However, these variables violated another major requirement for good instruments: relevance. Their correlations with the endogenous variables were rather low ${ }^{49}$. We use the most promising set: the Anderson-Hsiao instruments.

\section{Results and Policy Implications}

Results associated with the regressions on the dummy variable/import tariffs specification (specification (3"')) matched those prevalent in the literature: the dummy variable was insignificant, signaling that RIAs do not have an impact on growth in member countries. The results are not reported here ${ }^{50}$.

For the sake of brevity, we do not present and discuss every step and detail of each country's econometric results, although we will refer to them in the overall analysis ${ }^{51}$ and provide an overview in table 3 . Table 2 reports the results of the 3SLS heteroskedasticity and auto-correlation corrected results for each industry across the three countries related to equation $\left(3^{\prime \prime}\right)$. The $\log$ difference of real output is the dependent variable. The table includes terms

\footnotetext{
${ }^{47}$ Harrison uses $\log$ of nominal exchange rates, log of price index for energy, the log of sectoral wages and the $\log$ of debt. Based on her work we use : $\log$ of nominal exchange rates $\log$ of price of oil and manufacturing sector wages. Burnside (1996) analyses and ranks 5 alternative instrument sets. We tried one of the better performing and higher ranked ones: the current and three lagged values of growth rate of world oil price. However, as Hall points out, this instrument set is suspicious. Other instrument sets Burnside suggests (including Hall's) were not available for the set of country in our study.

48 Note however that this test is actually a joint null hypothesis of correct model specification and validity of the instrument matrix (Davidson \& Mackinnon, 1993).

49 The results obtained from these IV exercise involving Burnside's and Harrison's were mixed and non-robust. Equation (4) coefficient estimates (especially those of within-industry scale) tended to vary greatly without being significant (or significantly different from 1 in the case of the scale term). Burnside (1996) points out that this may be due to the high correlation between aggregate IVs and the external economy term. He recommends use of more industry specific IVs, which in our case are not available consistently across three countries.

${ }^{50}$ But are available from the author upon request.

${ }^{51}$ These results are available from the author upon request
} 
capturing industry and cross-industry scales, and electricity as a proxy for capacity utilization. It also contains alternative measures for regional integration and unilateral liberalization.

Panels two and three of table two provide several insights and we draw three main conclusions.

Our first set of conclusions is related to the industry level scales. We find that the scale coefficients range from 0.693 to 1.412 and are significantly different from zero, supporting Burnside (1996) 's argument that there is significant heterogeneity among the industries ${ }^{52}$. The heterogeneity of industry level economies of scale was confirmed by the country specific analysis $^{53}$. Therefore, the benefits of regional integration touted by the theoretical literature may only accrue to a select number of industries. Country-industry specific analysis (table 3) supports this aggregate analysis.

We verify that when cross industry scales are significant, they are so for a handful of industries (tobacco, industrial chemicals, etc,...). However, even when significant, they are very small and negative. Country-industry specific level analysis supports this result ${ }^{54}$. Our results contradict those of Caballero and Lyons (1990) who find the high and consistent positive output spillovers across industries for two out of the four countries in their study and in their 1992 study on U.S. manufacturing. On the other hand, the estimates match Basu and Fernald's (1995) work where they re-appraise Caballero and Lyons' 1992 analysis, correcting it for the use of value added data and the assumption of perfect competition. Basu and Fernald find that across-industry scale is negative, and in the scale of 0.02 to 0.035 . Our aggregate estimates range from 0.0002 to 0.0337 . Our country-industry specific industry (reported in table 3 ) support our aggregate analysis.

The final set of results addresses the impact of intermediate import variety on output growth. Our variety measures are positive and significant for only a few industries. Second, the effect of imported intermediate input variety (measured either by change in number of suppliers or growth in import variety) is industry specific and small (all but one case have a coefficient smaller than one). A one percent change in intermediate variety will generally lead to less than one percent growth in industry specific growth. This is reassuring since we did not expect very

\footnotetext{
${ }^{52} \mathrm{~A}$ large number of them are also significantly different than 1 .

${ }^{53}$ Here, the coefficients' range was wider, but heterogeneity was definitely and significantly present.

${ }^{54}$ See footnote 50 .
} 
large effects given the fact that variety impacts are second order effects. Also, not all industries should be affected (or affected equally) by imported intermediate input varieties. Third, there is weak evidence that when the ROW variety measures are significant, they are positive two thirds of the time. The results for the regional varieties in panels two and three are much weaker, possibly signaling non-relevance of regional varieties of intermediate inputs to member country industrial growth.

More dis-aggregated country and industry specific analysis (see summary in table 3) points to differentiated performance across the three Andean countries, nonetheless supporting the more widespread positive influence of unilateral liberalization. For instance, in Ecuador changes in ROW varieties have positive impact on 8 out of 19 industries, concentrated mostly on industries using intermediate inputs. While less evident in Colombia, ROW varieties affect three industries that depend on intermediate inputs (e.g. electrical machinery, transport equipment). On the other hand, the impact of the unilateral liberalization is not as strongly captured in Bolivia. We can not detect a pattern in our results favoring industries using intermediate inputs. The effects of regional varieties - when significantly present as in the case of Colombia - are generally negative and concentrated in the more basic industries such as food and tobacco.

Finally, we also estimated equation ( 3 "') to capture the cross-effect regional revival and unilateral liberalization may have on within and cross-industry externality. This last exercise did not net us much insight. In general cross-effect terms were very small and non-significant. One obvious reason for this set of results is the built-in multi-collinearity between cross-effect and original terms.

\section{Policy Implications and Future Research.}

The three Andean Countries in our study have very small, negative external economies. These results reject the argument proposed by Caballero and Lyons (1990, 1992) that large positive externalities exist at the industrial level. I also find that there is significant heterogeneity in within industry externalities. The combination of these two results casts doubt on the argument that countries may benefit from RIA because of industry and cross-industry scale effects. In fact, a handful of industries may benefit from industry scale effects, but no cross- 
industry effects appear present in the sense intended by the theoretical literature. Countryindustry specific analysis lends support to this conclusion.

With regards to our capturing the impact of the revival of the Andean Pact - while controlling for the simultaneous unilateral liberalization its members implemented - via the imported intermediate input variety channel we obtain mixed results.

At the cross country level (table 2, panels one and two) our variety measures have a significant impact on a handful of industries' growth. Within this set, ROW variety measures seem to have a generally positive impact on industrial output. This lends preliminary support to our argument that unilateral liberalization will have positive impact on output growth via the imported intermediate input channel. Our regional variety has much more of a mixed impact, potentially supporting the argument that we should not expect a noticeable impact of variety on industrial growth within a South-South arrangement. Country specific analysis (table 3 ) lends general support to our assessment.

A potential avenue for further investigation lies in further refining our import variety measures to provide us with more insightful results. The variety series here were calculated on a rather aggregate 3-digit ISIC level. We hope to replicate this analysis using four-digit SITC (commodity based). This dis-aggregation will capture more variations in our variety measures. 
Table 1: Mean and Standard Deviation of Supplier and Variety Series by Country:

\begin{tabular}{|c|c|c|c|c|c|c|c|c|c|c|c|c|}
\hline Bolivia & $\begin{array}{l}\text { Regional } \\
\text { suppliers }\end{array}$ & & $\begin{array}{l}\text { Regional } \\
\text { suppliers }\end{array}$ & & $\begin{array}{l}\text { Non- } \\
\text { regional } \\
\text { Supplier }\end{array}$ & & & & $\begin{array}{l}\text { Growth } \\
\text { in } \\
\text { Regional } \\
\text { variety } \\
\end{array}$ & & $\begin{array}{l}\text { Growth } \\
\text { in Non- } \\
\text { regional } \\
\text { variety }\end{array}$ & \\
\hline & Mean & Std Dev. & $\begin{array}{l}\text { Initial } \\
\text { number }\end{array}$ & $\begin{array}{l}\text { Final } \\
\text { number }\end{array}$ & Mean & Std. Dev & $\begin{array}{l}\text { Initial } \\
\text { number }\end{array}$ & $\begin{array}{l}\text { Final } \\
\text { number }\end{array}$ & Mean & Std Dev. & Mean & Std. Dev \\
\hline 1 Food products & 3.615 & 0.6373 & 4 & 4 & 30.5 & 4.71 & 30 & 32 & 0.0007 & 0.004 & -0.0006 & 0.0203 \\
\hline 2 Beverages & $3 . \overline{423}$ & 0.7027 & 3 & 4 & 24.92 & 4.68 & 22 & 27 & -0.003 & 0.023 & 0.0044 & 0.0347 \\
\hline 3 Tobacco & 2.231 & 0.9923 & 3 & 4 & 17.65 & 3.03 & 16 & 18 & -0.006 & 0.037 & 0.0192 & 0.1532 \\
\hline 4 Textiles & 0.077 & 0.2717 & 0 & 0 & 7.115 & 2.21 & 10 & 8 & 0.0 & 0.0 & 0.0197 & 0.1866 \\
\hline 5 Wearing apparel & 3.653 & 0.6238 & 4 & 4 & 36.769 & 4.25 & 33 & 45 & -0.0004 & 0.033 & 0.0059 & 0.0334 \\
\hline 6 Footwear & 1.884 & 1.3384 & 2 & 4 & 13.846 & 4.04 & 9 & 21 & 0.0080 & 0.027 & -0.0839 & 0.4128 \\
\hline 7 Wood prods & 2.269 & 1.2824 & 4 & 3 & 12.115 & 4.89 & 8 & 23 & 0.0000 & 0.022 & 0.0515 & 0.2148 \\
\hline 8 Fumiture & 2.384 & 1.0228 & 2 & 3 & 17.269 & 3.03 & 14 & 18 & -0.0770 & 0.408 & -0.0152 & 0.1272 \\
\hline 9 Paper and prods & 3.000 & 0.8944 & 3 & 4 & 25.653 & 4.02 & 25 & 32 & 0.0514 & 0.186 & -0.0021 & 0.0238 \\
\hline 10 Printing and pub & 3.962 & 0.1961 & 4 & 4 & 36.462 & 7.08 & 26 & 38 & -0.0088 & 0.052 & 0.0116 & 0.0684 \\
\hline 11 Industrial chems & 3.538 & 0.6467 & 4 & 4 & 38 & 5.72 & 31 & 46 & -0.0006 & 0.007 & 0.0028 & 0.0153 \\
\hline 12 Rubber prods & 3.385 & 0.7524 & 2 & 4 & 29.462 & 3.58 & 29 & 32 & -0.0332 & 0.407 & -0.0017 & 0.0170 \\
\hline 13 Plastic prods & $3.46 \mathrm{I}$ & 0.8114 & 3 & 4 & 27.346 & 5.78 & 23 & 38 & -0.0045 & 0.037 & 0.0041 & 0.0248 \\
\hline 14 Glass prods & 3.423 & 0.7027 & 3 & 4 & 26.307 & 3.27 & 22 & 30 & 0.0089 & 0.052 & -0.0041 & 0.0280 \\
\hline 15 Other non-metallic & 2.269 & 0.7243 & 2 & 3 & 21.615 & 3.83 & 20 & 21 & -0.0001 & 0.005 & 0.0040 & 0.1705 \\
\hline 16 Iron and steel & 2.5 & 0.9055 & 2 & 4 & 27.038 & 3.29 & 23 & 31 & 0.0018 & $0 . \overline{016}$ & 0.0023 & 0.0165 \\
\hline 17 Fab. Metal prods & 3.961 & 0.1961 & 4 & 4 & 43.846 & 7.49 & 24 & 58 & -0.0002 & 0.001 & -0.0023 & 0.0240 \\
\hline 18 Machinery etc. elec & 3.961 & 0.1961 & 4 & 4 & 45.769 & 6.87 & 38 & 64 & -0.0042 & 0.023 & 0.0037 & 0.0197 \\
\hline 19 Machinery elec. & 3.962 & 0.1961 & 4 & 4 & 42.192 & 6.62 & 38 & 52 & 0.0014 & 0.007 & 0.0058 & 0.0458 \\
\hline 20 Transport equip. & 3.769 & 0.4297 & 3 & 4 & 39.692 & 7.58 & 32 & 52 & 0.0233 & 0.115 & -0.0032 & 0.0227 \\
\hline 21 Prof and scientific & 3.615 & 0.6970 & 4 & 1 & 34.538 & 5.54 & 27 & 43 & 0.0489 & 0.230 & -0.0043 & 0.0123 \\
\hline 22 Other manuf. prods & 3.769 & 0.5870 & 4 & 4 & 31.730 & 5.34 & 27 & 38 & 0.0121 & 0.113 & 0.0038 & 0.0203 \\
\hline
\end{tabular}

Data for initial year is 1972. Final year is 1995 
Table 1 - continued

\begin{tabular}{|c|c|c|c|c|c|c|c|c|c|c|c|c|}
\hline Colombia & $\begin{array}{l}\text { Regional } \\
\text { suppliers }\end{array}$ & & & & $\begin{array}{l}\text { Non- } \\
\text { regional } \\
\text { Supplier }\end{array}$ & & & & $\begin{array}{l}\text { Growth } \\
\text { in } \\
\text { Regional } \\
\text { variety }\end{array}$ & & $\begin{array}{l}\text { Growth } \\
\text { in Non- } \\
\text { regional } \\
\text { variety }\end{array}$ & \\
\hline & Mean & Std Dev. & $\begin{array}{l}\text { Initial } \\
\text { number* }\end{array}$ & $\begin{array}{l}\text { Final } \\
\text { number }\end{array}$ & Mean & Std. Dev & $\begin{array}{l}\text { Initial } \\
\text { number }\end{array}$ & $\begin{array}{l}\text { Final } \\
\text { number }\end{array}$ & Mean & Std Dev. & Mean & Std. Dev \\
\hline 1 Food products & 3.269 & 0.452 & 3 & 4 & 37.038 & 9.463 & 28 & 61 & 0.00045 & 0.00227 & -0.0157 & 0.0899 \\
\hline 2 Beverages & 2.846 & 0.543 & 3 & 4 & 33.385 & 9.130 & 22 & 48 & -0.00053 & 0.01875 & -0.0048 & 0.0342 \\
\hline 3 Tobacco & 3.038 & 0.662 & 2 & 4 & 23.769 & 4.860 & 23 & 29 & 0.0040 & 0.1866 & -0.0011 & 0.1492 \\
\hline 4 Textiles & 1.455 & 0.820 & . & 2 & 4.4231 & 2.003 & 3 & 5 & 0.1620 & 0.4595 & 0.0383 & 0.1911 \\
\hline 5 Wearing apparel & 2.769 & 0.863 & 1 & 4 & 41.077 & 14.65 & 29 & 66 & 0.1002 & 0.3848 & 0.0100 & 0.0256 \\
\hline 6 Footwear & 1.913 & 1.164 & . & 4 & 20.384 & 9.047 & 16 & 42 & 0.0844 & 0.2775 & 0.0087 & 0.1740 \\
\hline 7 Wood prods & 1.684 & 1.157 & . & 4 & 12.923 & 10.714 & 4 & 41 & 0.0010 & 0.1381 & 0.0361 & 0.1099 \\
\hline 8 Furniture & 2.333 & 1.007 & 1 & 4 & 26.461 & 10.206 & 19 & 52 & 0.0195 & 0.7755 & -0.0148 & 0.0673 \\
\hline 9 Paper and prods & 2.307 & 0.837 & 2 & 4 & 32.846 & 7.035 & 28 & 53 & 0.1269 & 0.7844 & -0.0042 & 0.0242 \\
\hline 10 Printing and pub & 3.154 & 0.464 & 4 & 4 & 35.116 & 9.643 & 26 & 60 & -0.005 & 0.0698 & 0.0040 & 0.0127 \\
\hline 11 Industrial chems & 3.500 & 0.510 & 3 & 3 & 57.231 & 15.822 & 40 & 83 & 0.0002 & 0.0008 & -0.0006 & 0.0112 \\
\hline 12 Rubber prods & 2.640 & 0.907 & 1 & 3 & 38.538 & 10.045 & 23 & 61 & 0.0179 & 0.2340 & 0.0012 & 0.0118 \\
\hline 13 Plastic prods & 2.154 & 0.967 & 1 & 3 & 31.115 & 14.406 & 24 & 66 & -0.1401 & 0.9314 & -0.0107 & 0.0540 \\
\hline 14 Glass prods & 2.308 & 0.617 & 2 & 3 & 29.692 & 8.2061 & 24 & 49 & -0.0131 & 0.1694 & 0.0082 & 0.0312 \\
\hline 15 Other non-metallic & 2.320 & 0.802 & 1 & 4 & 31.038 & 8.3975 & 23 & 50 & 0.0343 & 0.1496 & 0.0023 & 0.0114 \\
\hline 16 Iron and steel & 2.577 & 0.809 & 1 & 3 & 40.500 & 9.1356 & 29 & 56 & 0.0314 & 0.1692 & -0.0004 & 0.0103 \\
\hline 17 Fab. Metal prods & 3.346 & 0.562 & 3 & 4 & 49.538 & 13.139 & 35 & 79 & 0.0028 & 0.0123 & 0.0021 & 0.0257 \\
\hline 18 Machinery etc. elec & 3.615 & 0.571 & 3 & 4 & 60.500 & 15.518 & $\overline{43}$ & 94 & 0.0075 & 0.0298 & -0.0008 & 0.0145 \\
\hline 19 Machinery elec. & 3.191 & 0.491 & 3 & 4 & 52.691 & 14.385 & 35 & 88 & 0.0002 & 0.0037 & -0.0033 & 0.0327 \\
\hline 20 Transport equip. & 3.423 & 0.504 & 3 & 3 & 50.115 & 12.729 & 35 & 81 & 0.0001 & 0.0015 & -0.0032 & 0.0179 \\
\hline 21 Prof and scientific & 2.692 & 0.838 & 1 & 3 & 46.38 & 9.826 & 35 & 65 & 0.1004 & 0.5821 & 0.0016 & 0.0121 \\
\hline 22 Other manuf. prods & 3.038 & 0.445 & 2 & 3 & 36.269 & 10.697 & 25 & 56 & -0.0041 & 0.0544 & -0.0076 & 0.0279 \\
\hline
\end{tabular}

Data for initial year is 1972 . Final year is 1995 
Table 1 - continued

\begin{tabular}{|c|c|c|c|c|c|c|c|c|c|c|c|c|}
\hline Ecuador & $\begin{array}{l}\text { Regional } \\
\text { suppliers }\end{array}$ & & & & $\begin{array}{l}\text { Non- } \\
\text { regional } \\
\text { Supplier }\end{array}$ & & & & $\begin{array}{l}\text { Growth } \\
\text { in } \\
\text { Regional } \\
\text { variety } \\
\end{array}$ & & $\begin{array}{l}\text { Growth } \\
\text { in Non- } \\
\text { regional } \\
\text { variety }\end{array}$ & \\
\hline & Mean & Std Dev. & $\begin{array}{l}\text { Initial } \\
\text { number* }\end{array}$ & $\begin{array}{l}\text { Final } \\
\text { number }\end{array}$ & Mean & Std. Dev & $\begin{array}{l}\text { Initial } \\
\text { number }\end{array}$ & $\begin{array}{l}\text { Final } \\
\text { number }\end{array}$ & Mean & Std Dev. & Mean & Std. Dev \\
\hline 1 Food products & 2.538 & 0.706 & 2 & 4 & 28.846 & 4.360 & 26 & 32 & 0.0288 & 0.211 & 0.0130 & 0.1187 \\
\hline 2 Beverages & 2.461 & 0.647 & 3 & 3 & 28.731 & 5.126 & 25 & 35 & 0.0037 & 0.171 & 0.0088 & 0.0375 \\
\hline 3 Tobacco & 1.800 & 0.768 & 1 & 3 & 21.461 & 4.966 & 17 & 30 & 0.0196 & 0.944 & -0.005 & 0.0673 \\
\hline 4 Textiles & 1.333 & 0.577 & . & 1 & 2.647 & 0.996 & 3 & 2 & -2.332 & . & 0.1368 & 0.7355 \\
\hline 5 Wearing apparel & 2.731 & 0.667 & 2 & 4 & 35.076 & 4.326 & 36 & 47 & -0.0019 & 0.0044 & -0.0037 & 0.0155 \\
\hline 6 Footwear & 1.909 & 1.221 & . & 4 & 11.192 & 4.578 & 10 & 23 & -0.0369 & 0.1172 & 0.0471 & 0.2670 \\
\hline 7 Wood prods & 1.500 & 0.759 & . & 3 & 7.520 & 7.030 & 1 & 25 & 0.0968 & 0.2817 & 0.0138 & 1.0251 \\
\hline 8 Furniture & 2.125 & 0.992 & 1 & 3 & 19.500 & 3.870 & 13 & 26 & -0.0178 & 0.5773 & 0.0012 & 0.0593 \\
\hline 9 Paper and prods & 2.692 & 0.471 & 2 & 3 & 27.801 & 3.710 & 25 & 39 & -0.0098 & 0.0507 & 0.0006 & 0.0150 \\
\hline 10 Printing and pub & 3.385 & 0.571 & 3 & 4 & 33.153 & 7.259 & 30 & 47 & 0.0097 & 0.0617 & -0.0068 & 0.0398 \\
\hline 11 Industrial chems & 3.038 & 0.196 & 3 & 3 & 49.462 & 5.743 & 41 & 57 & 0.0000 & 0.0017 & 0.0016 & 0.0139 \\
\hline 12 Rubber prods & 2.577 & 0.504 & 2 & 3 & 34.577 & 4.709 & 29 & 40 & 0.0025 & 0.0190 & 0.0037 & 0.0284 \\
\hline 13 Plastic prods & 2.885 & 0.516 & 3 & 4 & 32.384 & 5.352 & 24 & 46 & 0.0024 & 0.0112 & 0.0123 & 0.0577 \\
\hline 14 Glass prods & 2.577 & 0.643 & 2 & 4 & 28.846 & 3.812 & 24 & 39 & 0.0002 & 0.0006 & 0.0029 & 0.0248 \\
\hline 15 Other non-metallic & 2.769 & 0.430 & 3 & 3 & 27.885 & 4.082 & 20 & 34 & 0.0022 & 0.0161 & -0.0135 & 0.1443 \\
\hline 16 Iron and steel & 2.962 & 0.528 & 1 & 3 & 32.308 & 3.947 & 28 & 38 & -0.0184 & 0.2996 & 0.0127 & 0.0910 \\
\hline 17 Fab. Metal prods & 3.346 & 0.562 & 3 & 4 & 44.115 & 5.022 & 39 & 54 & 0.0022 & 0.0143 & 0.0091 & 0.0305 \\
\hline $\begin{array}{l}18 \text { Machinery etc. } \\
\text { non- elec }\end{array}$ & 3.615 & 0.496 & 3 & 4 & 51.385 & 7.829 & 40 & 66 & -0.0008 & 0.0053 & 0.0067 & 0.0423 \\
\hline 19 Machinery elec. & 3.346 & 0.562 & 3 & 4 & 43.962 & 6.069 & 38 & 49 & -0.0010 & 0.0106 & -0.0083 & 0.0253 \\
\hline 20 Transport equip. & 3.269 & 0.604 & 4 & 4 & 41.269 & 7.492 & 29 & 52 & -0.0012 & 0.0288 & -0.0008 & 0.0195 \\
\hline 21 Prof and scientific & 2.962 & 0.720 & 2 & 3 & 39.038 & 4.565 & 32 & 43 & 0.01311 & 0.0736 & 0.0070 & 0.0584 \\
\hline 22 Other manuf. prods & 2.769 & 0.710 & 3 & 4 & 32.769 & 5.085 & 30 & 45 & 0.0047 & 0.0336 & 0.0110 & 0.0597 \\
\hline
\end{tabular}

Data for initial year is 1972 . Final year is 1995 
Table 2: Andean Pact Industry specific results.

Panel 1 - regional and ROW variety change

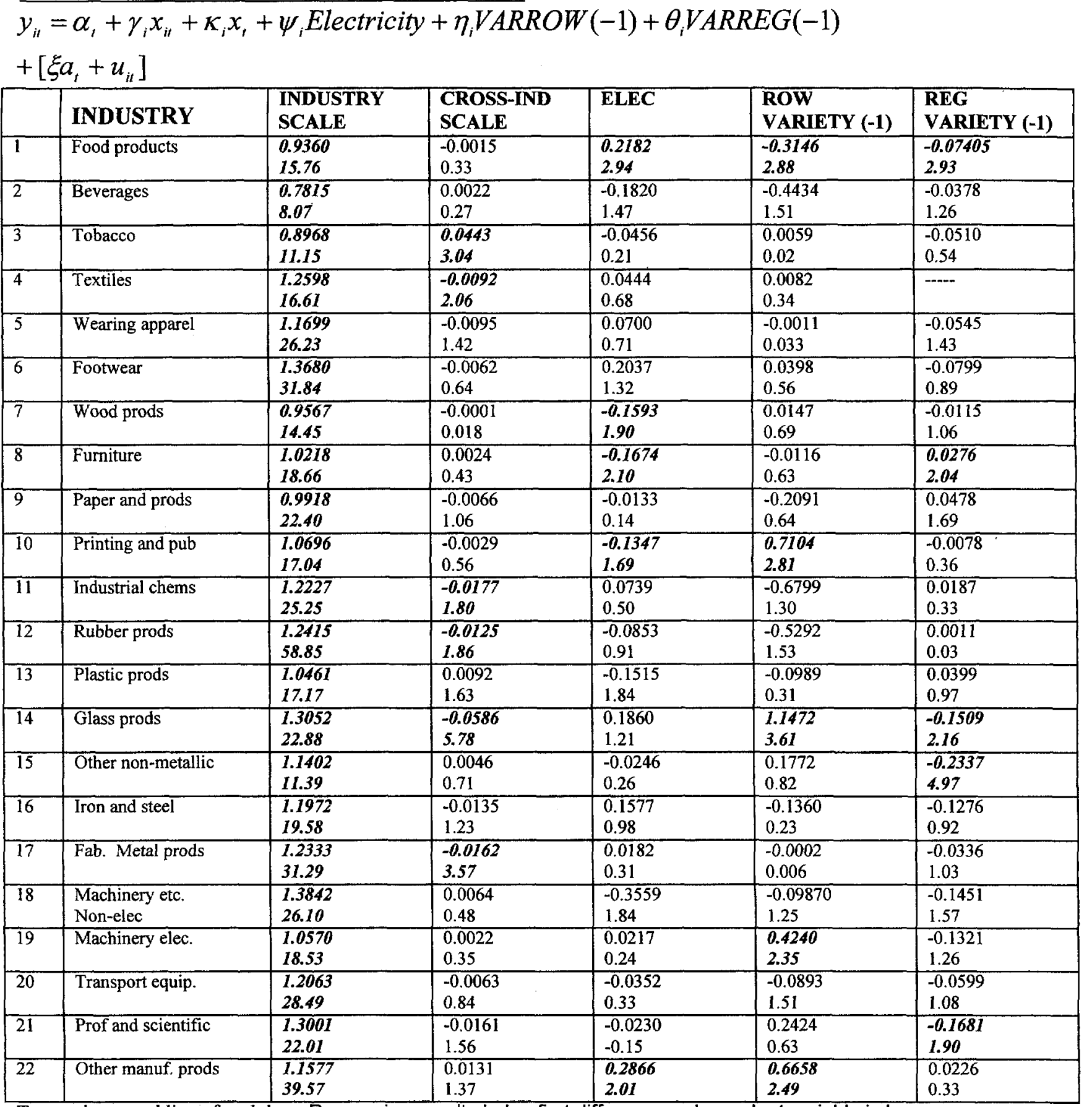

$\mathrm{T}$-stats in second line of each box. Regression results $\ln \log$ first differences- dependent variable is log

difference of real output. 
Table 2: Andean Pact Industry specific results

Panel 2 - regional and ROW suppliers

$y_{i t}=\alpha_{t}+\gamma_{i} x_{i t}+\kappa_{i} x_{t}+\psi_{i}$ Electricity $+\eta_{i} \operatorname{SUPLROW}(-1)+\theta_{i} \operatorname{SUPLREG}(-1)$

$+\left[\xi a_{i}+u_{i t}\right]$

\begin{tabular}{|c|c|c|c|c|c|c|}
\hline & INDUSTRY & $\begin{array}{l}\text { INDUSTRY } \\
\text { SCALE }\end{array}$ & $\begin{array}{l}\text { CROSS-IND } \\
\text { SCALE }\end{array}$ & ELEC & $\begin{array}{l}\text { ROW } \\
\text { SUPPLIER(-1) }\end{array}$ & $\begin{array}{l}\text { REG } \\
\text { SUPPLIER }(-1)\end{array}$ \\
\hline 1 & Food products & $\begin{array}{l}0.9184 \\
17.17\end{array}$ & $\begin{array}{l}-0.0010 \\
0.22\end{array}$ & $\begin{array}{l}0.2393 \\
3.33\end{array}$ & $\begin{array}{l}-0.0211 \\
0.34\end{array}$ & $\begin{array}{l}-0.1948 \\
5.69\end{array}$ \\
\hline 2 & Beverages & $\begin{array}{l}0.6927 \\
6.23 \\
\end{array}$ & $\begin{array}{l}0.0034 \\
0.43\end{array}$ & $\begin{array}{l}-0.1879 \\
1.56\end{array}$ & $\begin{array}{l}-0.2851 \\
2.54\end{array}$ & $\begin{array}{l}0.1465 \\
2.19\end{array}$ \\
\hline 3 & Tobacco & $\begin{array}{l}0.9404 \\
11.10\end{array}$ & $\begin{array}{l}0.0300 \\
2.03\end{array}$ & $\begin{array}{l}-0.027 \\
0.13\end{array}$ & $\begin{array}{l}0.1371 \\
0.82\end{array}$ & $\begin{array}{l}-0.0071 \\
0.07\end{array}$ \\
\hline 4 & Textiles & $\begin{array}{l}1.2905 \\
16.62 \\
\end{array}$ & $\begin{array}{l}-0.0093 \\
2.06 \\
\end{array}$ & $\begin{array}{l}0.0377 \\
0.57 \\
\end{array}$ & $\begin{array}{l}-0.0824 \\
0.13 \\
\end{array}$ & $\cdots$ \\
\hline 5 & Wearing apparel & $\begin{array}{l}1.1350 \\
24.67 \\
\end{array}$ & $\begin{array}{l}-0.0014 \\
0.22\end{array}$ & $\begin{array}{l}0.0924 \\
0.99\end{array}$ & $\begin{array}{l}-0.3373 \\
3.56\end{array}$ & $\begin{array}{l}-0.0345 \\
0.63\end{array}$ \\
\hline 6 & Footwear & $\begin{array}{l}1.4061 \\
33.34 \\
\end{array}$ & $\begin{array}{l}-0.0083 \\
0.84 \\
\end{array}$ & $\begin{array}{l}0.1614 \\
1.05 \\
\end{array}$ & $\begin{array}{l}-0.0647 \\
0.35 \\
\end{array}$ & $\begin{array}{l}0.0399 \\
0.35 \\
\end{array}$ \\
\hline 7 & Wood prods & $\begin{array}{l}0.9072 \\
15.64 \\
\end{array}$ & $\begin{array}{l}-0.0021 \\
0.35 \\
\end{array}$ & $\begin{array}{l}-0.1810 \\
2.24 \\
\end{array}$ & $\begin{array}{l}0.1226 \\
2.23 \\
\end{array}$ & $\begin{array}{l}0.0332 \\
1.31 \\
\end{array}$ \\
\hline 8 & Furniture & $\begin{array}{l}1.008 \\
17.10\end{array}$ & $\begin{array}{l}0.0075 \\
1.27\end{array}$ & $\begin{array}{l}-0.1751 \\
2.25\end{array}$ & $\begin{array}{l}0.0237 \\
0.44\end{array}$ & $\begin{array}{l}-0.439 \\
1.69\end{array}$ \\
\hline 9 & Paper and prods & $\begin{array}{l}0.9662 \\
20.76\end{array}$ & $\begin{array}{l}-0.0082 \\
1.32\end{array}$ & $\begin{array}{l}-0.0299 \\
0.34\end{array}$ & $\begin{array}{l}0.1332 \\
1.21\end{array}$ & $\begin{array}{l}-0.4069 \\
0.61\end{array}$ \\
\hline 10 & Printing and pub & $\begin{array}{l}1.0345 \\
16.35 \\
\end{array}$ & $\begin{array}{l}-0.0 \overline{0} 2 \\
1.03\end{array}$ & $\begin{array}{l}-0.0537 \\
0.76 \\
\end{array}$ & $\begin{array}{l}0.1621 \\
2.04 \\
\end{array}$ & $\begin{array}{l}0.1169 \\
2.33\end{array}$ \\
\hline 11 & Industrial chems & $\begin{array}{l}1.1806 \\
21.72 \\
\end{array}$ & $\begin{array}{l}-0.0199 \\
2.04 \\
\end{array}$ & $\begin{array}{l}0.0681 \\
0.48 \\
\end{array}$ & $\begin{array}{l}-0.0241 \\
0.10 \\
\end{array}$ & $\begin{array}{l}0.2378 \\
1.58\end{array}$ \\
\hline 12 & Rubber prods & $\begin{array}{l}1.2650 \\
58.29\end{array}$ & $\begin{array}{l}-0.0177 \\
2.62\end{array}$ & $\begin{array}{l}-0.0782 \\
0.84\end{array}$ & $\begin{array}{l}0.0722 \\
0.50\end{array}$ & $\begin{array}{l}-0.0609 \\
0.61\end{array}$ \\
\hline 13 & Plastic prods & $\begin{array}{l}.0286 \\
16.57 \\
\end{array}$ & $\begin{array}{l}0.0089 \\
1.63 \\
\end{array}$ & $\begin{array}{l}-0.1520 \\
1.91 \\
\end{array}$ & $\begin{array}{l}0.0463 \\
0.39 \\
\end{array}$ & $\begin{array}{l}-0.1603 \\
2.37 \\
\end{array}$ \\
\hline 14 & Glass prods & $\begin{array}{l}1.2496 \\
18.89\end{array}$ & $\begin{array}{l}-0.0424 \\
4.10\end{array}$ & $\begin{array}{l}-0.0424 \\
1.69\end{array}$ & $\begin{array}{l}-0.5550 \\
2.60\end{array}$ & $\begin{array}{l}-0.0237 \\
0.18\end{array}$ \\
\hline 15 & Other non-metallic & $\begin{array}{l}0.9869 \\
8.84\end{array}$ & $\begin{array}{l}0.0030 \\
0.43\end{array}$ & $\begin{array}{l}0.0035 \\
0.04 \\
\end{array}$ & $\begin{array}{l}0.3552 \\
2.42 \\
\end{array}$ & $\begin{array}{l}0.0895 \\
1.01 \\
\end{array}$ \\
\hline 16 & Iron and steel & $\begin{array}{l}1.2402 \\
18.50\end{array}$ & $\begin{array}{l}-0.0181 \\
1.64\end{array}$ & $\begin{array}{l}0.1531 \\
0.95\end{array}$ & $\begin{array}{l}0.2594 \\
1.17\end{array}$ & $\begin{array}{l}-0.0019 \\
0.024\end{array}$ \\
\hline 17 & Fab. Metal prods & $\begin{array}{l}1.2215 \\
26.19\end{array}$ & $\begin{array}{l}-0.0156 \\
3.27\end{array}$ & $\begin{array}{l}0.0156 \\
0.17\end{array}$ & $\begin{array}{l}0.0566 \\
0.76\end{array}$ & $\begin{array}{l}-0.0486 \\
1.28\end{array}$ \\
\hline 18 & Machinery etc. elec & $\begin{array}{l}.4122 \\
27.18 \\
\end{array}$ & $\begin{array}{l}0.0089 \\
0.68 \\
\end{array}$ & $\begin{array}{l}-0.3511 \\
1.84\end{array}$ & $\begin{array}{l}-0.2627 \\
1.26 \\
\end{array}$ & $\begin{array}{l}-0.2527 \\
2.50 \\
\end{array}$ \\
\hline 19 & Machinery elec. & $\begin{array}{l}1.0263 \\
17.41\end{array}$ & $\begin{array}{l}0.0049 \\
0.76\end{array}$ & $\begin{array}{l}0.0603 \\
0.67\end{array}$ & $\begin{array}{l}-0.1691 \\
1.69\end{array}$ & $\begin{array}{l}0.0344 \\
0.50\end{array}$ \\
\hline 20 & Transport equip. & $\begin{array}{l}1.1783 \\
28.84\end{array}$ & $\begin{array}{l}-0.0037 \\
0.49\end{array}$ & $\begin{array}{l}-0.0444 \\
0.42 \\
\end{array}$ & $\begin{array}{l}-0.1888 \\
1.26\end{array}$ & $\begin{array}{l}0.0013 \\
0.013\end{array}$ \\
\hline 21 & Prof and scientific & $\begin{array}{l}1.3258 \\
22.28\end{array}$ & $\begin{array}{l}-0.0168 \\
1.62\end{array}$ & $\begin{array}{l}-0.0297 \\
0.20 \\
\end{array}$ & $\begin{array}{l}0.1483 \\
0.68 \\
\end{array}$ & $\begin{array}{l}-0.3415 \\
2.31\end{array}$ \\
\hline 22 & Other manuf. prods & $\begin{array}{l}.1343 \\
38.18 \\
\end{array}$ & $\begin{array}{l}0.0086 \\
0.91 \\
\end{array}$ & $\begin{array}{l}0.3018 \\
2.17 \\
\end{array}$ & $\begin{array}{l}.4836 \\
2.90 \\
\end{array}$ & $\begin{array}{l}-0.0638 \\
0.64 \\
\end{array}$ \\
\hline
\end{tabular}

$\mathrm{T}$-stats in second line of each box. Regression results In log first differences- dependent variable is log difference of real output. 
Table 3: Summary of Country specific results- Regional and ROW variety change

$$
\begin{aligned}
& y_{i t}=\alpha_{t}+\gamma_{i} x_{i t}+\kappa_{i} x_{i}+\psi_{i} \text { Electricity }+\eta_{i} \operatorname{VARROW}(-1)+\theta_{i} \operatorname{VARREG}(-1) \\
& +\left[\xi a_{i}+u_{i t}\right]
\end{aligned}
$$

\begin{tabular}{|c|c|c|c|c|c|}
\hline COUNTRY & $\begin{array}{l}\text { INDUSTRY } \\
\text { SCALE }\end{array}$ & $\begin{array}{l}\text { CROSS-IND } \\
\text { SCALE }\end{array}$ & ELEC & $\begin{array}{l}\text { ROW } \\
\text { VARIETY (-1) }\end{array}$ & $\begin{array}{l}\text { REG } \\
\text { VARIETY (-1) }\end{array}$ \\
\hline Bolivia & $\begin{array}{l}\text { 19 industries with } \\
\text { significant coeffs: } \\
\text { DRS:7 } \\
\text { CRS: } 2 \\
\text { IRS: } 10\end{array}$ & $\begin{array}{l}5 \text { industries have } \\
\text { very small. } \\
\text { positive and } \\
\text { significant coeffs. }\end{array}$ & $\begin{array}{l}7 \text { industries have } \\
\text { significant coeffs, } \\
\text { four of them } \\
\text { negative. }\end{array}$ & $\begin{array}{l}\text { industries; no } \\
\text { apparent } \\
\text { concentration in } \\
\text { industries using } \\
\text { intermediate } \\
\text { inputs. }\end{array}$ & 2 industries \\
\hline Colombia & $\begin{array}{l}\text { 14 industries } \\
\text { significant coeffs: } \\
\text { DRS: } 1 \\
\text { CRS: } 0 \\
\text { IRS: } 13\end{array}$ & $\begin{array}{l}5 \text { industries have } \\
\text { significant coeffs, } \\
\text { all very small. } 4 \text { of } \\
\text { them negative. }\end{array}$ & $\begin{array}{l}7 \text { industries have } \\
\text { significant coeffs, } \\
5 \text { are positive. }\end{array}$ & $\begin{array}{l}\text { industries } \\
\text { ( } 3 \text { positive: } \\
\text { Other non- } \\
\text { metallic prods, } \\
\text { Machinery elec. } \\
\text { And transport } \\
\text { equipment) }\end{array}$ & $\begin{array}{l}8 \text { industries } \\
\text { (6 negative: food, } \\
\text { tobacco, paper } \\
\text { prods, iron and } \\
\text { steel, fabricated } \\
\text { metal products) }\end{array}$ \\
\hline Ecuador & $\begin{array}{l}19 \text { industries } \\
\text { significant } \\
\text { coeffs:: } \\
\text { DRS: } 8 \\
\text { CRS: } 4 \\
\text { IRS: } 7\end{array}$ & $\begin{array}{l}3 \text { industries have } \\
\text { very small } \\
\text { negative and } \\
\text { significant coeffs. }\end{array}$ & $\begin{array}{l}5 \text { industries have } \\
\text { significant coeffs, } \\
\text { one of them } \\
\text { negative. }\end{array}$ & $\begin{array}{l}8 \text { industries; } \\
\text { Concentration in } \\
\text { industries } \\
\text { traditionally using } \\
\text { intermediate } \\
\text { inputs }(15,16,17, \\
18,20,21)\end{array}$ & 2 industries \\
\hline
\end{tabular}




\section{References and Bibliography}

Abbott, T.A., Z. Griliches and J.A. Hausman. 1989. "Short Run Movements in Productivity: Market Power Versus Capacity Utilization" (mimeo).

Baldwin, R. and E. Seghezza. 1996. Testing for Trade-induced Investment-led Growth. NBER Working Paper 5416.

1997. "International Integration and Investment-led growth in Developing Nations", paper prepared for the World Bank - IECIT.

Baldwin, R. E. and A. J. Venables. 1995. "Regional Economic Integration". Chapter 31 in Handbook of International Economics, Vol. III. Edited by G. Grossman and K. Rogoff, North Holland, Amsterdam.

Baltagi, B. 1995. Econometric Analysis of Panel Data. John Wiley \& Sons Publications, New York.

Basu, S. and J.G. Fernald. 1995. "Are Apparent Productive Spillovers a Figment of Specification Error? NBER Working Paper, \# 5073.

Burnside, G. Eichenbaum and Rebello. 1996. "Capital Utilization and Returns to Scale", NBER Annual Volume On Macroeconomics.

Burnside, G. 1996. "Production Function Regressions, Returns to Scale, and Externalities", Journal of Monetary Economics, 37, 177-201.

Brada J.C. and J.A. Mendez. 1988. "Notes: An Estimate of the Dynamic Effects of Economic Integration", The Review of Economics and Statistics, 163-168.

Caballero R. and R. Lyons. 1992. "External Effects in U.S. Procyclical Productivity" , Journal of Monetary Economics, 29, 209-225.

Caballero R. and R. Lyons. 1991. "External Effects and European Integration" in L.A. Winters and A.Venables (eds.) European Integration: Trade and Industry. Cambridge University Press.

Caballero R. and R. Lyons. 1990. "Internal Versus External Economies in European Industry", European Economic Review, 34, 805-830.

Caceres, L. R. 1994. "Central American Integration: Its Costs and Benefits", Cepal Review, 54, December, 111-128.

Cassella, A. 1996. "Large Countries, Small Countries and the Enlargement of Trade Blocs", European Economic Review, 40, 389-415. 
Coe, D and E. Helpman. 1995. "International R\&D Spillovers", European Economic Review, 39 , pg. 859-887.

Davidson, R. and J. G. Mackinnon. 1993. Estimation and Inference in Econometrics, Oxford University Press, Oxford.

De Melo, J., C. Montenegro and A Panagariya. 1993. "l'Integration Regionale Hier et Aujourd'hui", Revue d'Economie du Developpement, February, 7-48.

De Melo, J., A. Panagariya, and D. Rodrik. 1992. “ The New Regionalism: A Country Perspective", CEPR Discussion Paper No. 715, London.

Echavarria, J. J., 1998. "Trade Flows in the Andean Countries: Unilateral Liberalization or Regional preferences?", Organization of American States, Washington.

Edwards, E. 1994. "Trade and Industrial Policy Reform in Latin America", NBER paper No. 4772. Boston, MA.

Feenstra, R.C. 1994. "New Product Varieties and the Measurement of International Prices" The American Economic Review, Vol 84, No. 1, March, 157-177.

Freenstra, R.C. and J.R. Markusen. 1994. "Accounting for Growth with New Inputs", International Economic Review, 35, No. 2.

Feenstra, R. C., and D. Madani, T. Yang, C. Liang. 1999. "Testing Endogenous Growth in South Korea and Taiwan", Journal of Development Economics, Vol. 60, 317-341.

Foroutan, F. 1997. "Does Membership in an FTA Make a Country More or Less Protectionist?" Draft, May, International Trade Division, The World Bank.

Grossman, G. and E. Helpman. 1991. Innovation and Growth in the Global Economy. The MIT Press, Cambridge, MA.

Hall, Robert E. 1990. "Invariance Properties of Solow's Productivity Residual" in Growth/Productivity/Unemployment edited by Peter Diamond. MIT Press, Cambridge, MA, pg. $71-112$.

Hall, Robert E. 1988. "The Relation between Price and Marginal Cost in U.S. Industry" Journal of Political Economy, Vol. 96, No. 5, pg. 921-947.

Harrison, A. E. 1994. "Productivity, Imperfect Competition and Trade Reform", Journal of International Economics, 36, 53-73.

Henrekson, M, et. al. 1996. Growth Effects of European Integration, CEPR Discussion Paper No. 1465, September, London. 
Hsiao, C. 1993. Analysis of Panel Data. Econometric Society Monographs No. 11. Cambridge Univ. Press. Cambridge

Italianer, A. 1994. "Whither the Gains from European Economic Integration?", Revue Economique, No.3, May, 689-702.

International Monetary Fund. 1996. "Bolivia - recent economic developments". Washington, D.C.

International Monetary Fund. 1995. "Ecuador - Recent economic developments". Washington, D.C.

International Monetary Fund. 1994. "Colombia -Recent Economic Development- 1996" Washington, D.C.

Judge, G., et. al. 1985. Chapter 11 of The Theory And Practice of Econometrics, Second Edition. John Wiley \& Sons Publications, New York.

Madani, D. H. 1997. "Imperfect Competition, Economies of Scale and the Impact of Government Policies on Productivity: S. Korea and Taiwan, 1972-1991". Ph.D. Dissertation Manuscript, University of California, Davis.

Markusen, J. R. and A. J. Venables. 1998. "Foreign Direct Investment as a Catalyst for Industrial Development". Mimeo. DECRG, The World Bank.

Ng, Francis. 1994. Trade Liberalization Review. Mimeo. DECRG-Trade, World Bank.

Puga, D. and A. J. Venables. 1997. "Trading Arrangements and Industrial Development". Policy Research Working Paper No. 1787. The World Bank.

Rivera-Batiz, L. and D Xie. 1992. "Endogenous Growth in Open Economies" in American Economic Review Papers and Proceedings, Vol. 82, No. 2, May, 422-427.

Rivera-Batiz, L. and P. M. Romer. 1991. "Economic Integration and Endogenous Growth", Quarterly Journal of Economics, Vol. 56, Issue 2, May, 531-555.

Robson, P. 1993. "The New Regionalism and Developing Countries", Journal of Common Market Studies, Vol. 31, No. 3, September, 329-348.

Ruhashyankiko, J. 1997. “Does Regional Integration Create Specific Dynamic Effects?” Draft. DECRG (trade), World Bank.

Walz, Uwe. 1997. "Dynamic Effects of Economic Integration: A Survey",Open Economies Review, 8:3, 309-326. 
World Bank. 1990. "Ecuador - Development of Manufacturing: policies, performance and outlook", Report no. 8412-EC.

World Bank. 1994. Report no. 13067-BO.

World Bank report No. 15419-EC. 


\section{Appendix 1}

\section{The Caballero-Lyons Model}

Within the growth framework, Caballero and Lyons (1990) extend on the work by Solow (1956) and Hall $(1988,1990)$ to investigate the presence of internal versus external economies of scale.

Empirically, for each industry $i$ we start with an "augmented" growth equation where the impact of external economy is specifically represented by $E_{i l}$. All other variables have been

described above: $Y_{i t}=A_{i t} . f\left(K_{i t}, L_{i t}, E_{i t}\right)$. We also assume that the function is homogeneous of degree $\gamma$ (HOD $\gamma$ ) in capital $\left(K_{i t}\right)$ and labor $\left(L_{i t}\right)$ while HOD 1 in $E_{i t}$ and $A_{i t}$. So that, equation (1) is now transformed into:

$$
d y_{i t}=\gamma\left[\alpha_{i t l} d l_{i t}+\alpha_{i t k} d k_{i t}\right]+d e_{i t}+d a_{i t}
$$

or

$$
d y_{i t}=\gamma d x_{i t}+\left(d e_{i t}+d a_{i t}\right)
$$

where $d x_{i t}=\left[\alpha_{i l l} d l_{i t}+\alpha_{i t k} d k_{i t}\right]$ and $\alpha_{i t l}, \alpha_{i t k}$ are cost shares of labor and capital. $\gamma$ represents internal (within industry) economies of scale (here, and for the moment, we constrain $\gamma$ to be the same for all industries) $d a_{i t}$ is productivity (TFP) index. $d e_{i t}$ represents the external economy (cross-industry) index and can be represented by any simple form depicting the source of externalities postulated. Here, we choose a simple linear form as:

$$
d e_{i t}=\beta d y_{1}+d u_{i t}
$$


$d u_{i t}$ is the error term and $y_{t}$ is the aggregate (manufacturing sector) output. Plugging (3) into (2):

$$
d y_{i t}=\gamma d x_{i t}+\beta d y_{t}+d a_{i t}+d u_{i t}
$$

If we aggregated equation (4) over all industries $i$, we would get:

$$
d y_{1}=\frac{\gamma}{1-\beta} d x_{1}+\frac{1}{1-\beta} d a_{1}
$$

where $d x_{t}=\sum_{i} d x_{i t}$. At the aggregate level, equation (5) shows more than just internal (within industry) economies. The stronger the presence of cross-industry externality (i.e. the larger $\beta$ ), the more the OLS estimates of $\gamma$ will be biased upward. Plugging (5) back into (4) we obtain:

(6) $\quad d y_{i t}=\gamma d x_{i t}+\frac{\beta \gamma}{1-\beta} d x_{t}+\frac{1}{1-\beta} d a_{t}+d u_{i t}$

C\&B (1990) use equations (2a) and (6) to disentangle the presence and significance of internal versus external economies of scale.

In estimating equation (2a) we need to take into consideration that the industry level and aggregate level inputs $\left(d x_{i t}\right.$ and $\left.d x_{t}\right)$ will be positively correlated. In the presence of external effects, therefore, the estimated coefficient in equation (2a), called $\theta$ from now on, will be upward biased. In fact, according to Caballero and Lyons (1990), 


$$
\operatorname{plim} \theta=\gamma+\psi \frac{\gamma \beta}{1-\beta}, \text { where } \psi=\frac{\sigma_{d x}, d x_{i}}{\sigma_{d x_{i}}^{2}}
$$

b. Using equation (6) they estimate the coefficients $\gamma$ and $\frac{\gamma \beta}{1-\beta}$ and deduce $\beta$. They

also obtain an estimate for $\theta$ and proceed to compare these coefficients in order to identify the impact (or lack thereof) of within vs. external economies of scale ${ }^{55}$.

\footnotetext{
${ }^{55}$ Prior to introducing RIA proxies, we will briefly look at the existence of internal vs. external effects at the manufacturing as well as industry level (for each country). We are fully aware that this partial analysis will only provide us with biased results (since the equation is mis-specified), we however undertake it for illustrative reasons.

More specifically, we will proceed in sequential form in answering the following questions by estimating the above equations:

1. Do economies of scale (EOS) exist? For which countries, which industries?

2. Is this economies of scale within industries or across industries? In other words, what are the values of the coefficients $\gamma$ and $\beta$ ?

3. If we find significant economies of scale (either w/in or across), we need to consider alternative hypotheses (explanation/correlations) that may cause this result..

For instance, Abbot, Griliches and Hausman (1989) find that when they include capacity utilization, Hall's (1988) mark-up loses its significance. We therefore need to verify the sensitivity of our analysis to alternative specifications.

4. Analysis of the results will following outline:

- Existence of cross-industry externality should benefit these nations for it increases production efficiency.

- If there is no with-in industry externality then developing countries adhering to an RIA will not experience large agglomeration benefits suggested by the theoretical and simulation literature. This would raise questions about the value of integration (Caballero and Lyons, 1990).
} 


\section{Appendix 2}

\section{Theoretical Framework}

This appendix addresses two issues. In part one, we outline a new growth model that incorporates intermediate inputs/imports flow as carriers of foreign knowledge. It delineates how regionalism vs. open regionalism may affect this flow and by extension domestic industrial growth. In part two, it briefly discusses how the intermediate input/imports flow may affect within and cross-industry externality.

By definition regional integration arrangements (RIA) are preferential agreements and will discriminate against non-members. This discrimination is represented through differential tariff rates, market access, human capital and labor movements, and a host of other privileges.

The literature identifies three avenues for the RIA to affect the member economies: the redundancy, allocation and scale effects. The redundancy effect addresses the process of eliminating duplicative research and the gains from it. The allocation effect addresses the within (and cross) country resources allocation due to regional integration. Movements of human capital to (away) the R\&D sector leads to increase (decrease) in the creation/production of knowledge domestically and to faster (slower) growth. Finally, the scale effect addresses the impact of an RIA on the incentives and dynamics of the R\&D sector (which here produces intermediate sector), and by extension the growth of the economy (see Walz, 1997).

For simplicity, we assume the absence of redundancies and abstract from allocation effects. We investigate the scale effect.

We use the framework of a new growth theory model to understand better the impact of a RIA on the growth of its members' industrial sector. We do not present a full fledge model here, rather, only state the aspects of the model we consider most relevant to our empirical analysis 
and hypothesis testing discussed in the main text. For instance, we abstract from stating and analyzing the full equilibrium and steady state conditions. Rivera-Batiz et. al. (1991, 1992), Puga and Venables (1997), Grossman and Helpman (1991, chapters 3, 9 and 11) and Ruhashyankiko (1997) provide full model analyzes (though with different basic assumptions).

We have opted for model qualifications that match the two regional agreements of interest. Theoretical abstractions were however unavoidable to make the analysis tractable.

\section{Part I. The outline of the growth model}

We assume a three-country model: two symmetric "southern" countries and a larger third comprising the rest of the world (ROW). The southern countries have comparative advantage in labor intensive production compared to the ROW, though still endowed with small R\&D sectors. They have similar economic structures, endowments and capital to labor ratios. Their identical capital to labor ratio is less than that of ROW. They innovate in the sense that a share of their new intermediate goods is truly original, while the rest is based on de-assembling and altering the design of imported intermediate inputs (imitation, copying, re-engineering). Hence the flow of new intermediate inputs from ROW, or in other words, the pool of knowledge provided by ROW, is essential for the long term growth of the R\&D sector and by extension the economy.

We assume a South-South or customs union arrangement ${ }^{56}$. While there are no internal tariffs to trade, a common external tariff exists. There are free human capital and labor

\footnotetext{
${ }^{56}$ We assume a customs union framework rather a common market set-up. In a common market, movement of factors of production allows the reallocation effect regional integration to kick in. However, the regional arrangements we are studying belie this theoretical set up now. Since we hope to develop empirically testable hypotheses, we opted for the framework (customs union) which is closer to the reality of the Andean Group. Even after agreeing to a common external tariff in 1994, the Andean Group diverges enough from a traditional CU that we can view it as a Free Trade Area: not all members are complying with the CU (Bolivia, Peru), there are still some protected industries in each country.
} 
movements within countries but not across countries. Assume also that interest rates are determined by world markets and are equalized across the world due to arbitrage.

We also assume a two-sector model, one sector producing final goods and the other creating and producing intermediate goods (called $R \& D$ sector for simplicity). That is in the R\&D sector innovators also produce the intermediate goods ${ }^{57}$.

The typical representative household maximizes its inter-temporal utility over a freely traded final good $Y$ :

$$
U_{T}=\int_{T}^{\infty} e^{-\rho(t-T)} \ln Y(t) d t
$$

Where $\rho$ is the discount rate. We assume that interest rates $r$ are set internationally so that $\rho=r$

We conceptualize that the dynamic effects of the RIA are channeled through the trade in differentiated intermediate goods. That is, trade is our vehicle for transfer of the knowledge essential to insure dynamic (long-term) growth via its role in creation of new input.

The underlying production function for final good industry $Y$ in country $i$ is:

$$
Y_{i}=\left(H_{i}^{y}\right)^{\alpha}\left(L_{i}^{y}\right)^{\beta}\left[\int_{0}^{N} x_{i}(j)^{\frac{\sigma-1}{\sigma}} d j\right]^{\frac{(1-\alpha-\beta) \sigma}{\sigma-1}}
$$

$H^{y}$ and $L^{y}$ are the factor inputs used to produce the final good $Y . x_{i,}(j)$ is the intermediate good from country $j$ and used in country $i$ (note that we can have $i=j$ ). $\sigma>1$ as elasticity of substitution between two intermediate inputs ${ }^{58}$.

\footnotetext{
${ }^{57}$ In combining the innovation and production of intermediate goods, we have circumvented a whole set of economic relationships such as decisions about the manner, and timing of payments on intellectual property and pattern rights. This abstraction was done to simplify the analysis. Rivera and Romer (1991) state that such an "institutional structure" supports a decentralized equilibrium in manufacturing.
} 
The intermediate good production is knowledge driven. In each southern country $i$, we assume the creation of intermediate goods in each industrial sector $Z$ is a general function of human capital invested in its innovation $\left(H_{z}^{x}\right)$ and the public pool of knowledge represented here by the number of overall available intermediate $(N)$ :

$$
x_{z}=f\left(H_{z}^{x}, N\right)
$$

such that the dynamic growth of intermediate inputs is determined by:

$$
\dot{x_{z}}=\left(H_{z}^{x}\right) N
$$

and will continue to grow in each industry $Z$ while:

$$
\pi_{x_{z}} \geq \frac{W^{H}}{N}
$$

where $\pi_{x_{x}}$ is discounted profits for producers/creators of intermediate inputs. $W^{H} / N$ is cost of innovation, with $W^{H}$ as wages (paid to human capital). The cost of innovation will decrease with the increased variety of intermediate goods $N$. We define $N \operatorname{as}^{59}$ :

$$
N=f\left(N_{\text {hom } e}, N_{\text {RIAparner }}, N_{\text {ROW }}\right)
$$

${ }^{58}$ The production function is more typically written as: $Y_{i}=\left(H_{i}^{y}\right)^{a}\left(L_{i}^{y}\right)^{b}\left[\int_{0}^{N} x_{i,}(j)^{\alpha} d j\right]^{\frac{(1-a-h)}{\alpha}}$, where $\alpha=\frac{\sigma-1}{\sigma}$, and $\frac{1}{\alpha}=\frac{\sigma}{\sigma-1}$, with elasticity of substitution as: $\sigma=\frac{1}{1-\alpha}$.

${ }^{59}$ Note that here we assume that knowledge brought in via intermediate inputs affects innovation in all industries equally. In other words, it enlarges the domestic pool of knowledge. Alternatively, we can be much more detailed about the nature and impact of the "imported knowledge". We can differentiate the nature of the knowledge to be industry specific (leading to within industry externality -i.e. agglomeration - alone: i.e. $N_{z}=f\left(N_{z, \text { hom } e}, N_{z, \text { RIAparner }}, \delta N_{z, \text { ROW }}\right)$ ) or as described above, general (thus contributing to overall industrial knowledge and therefore having a cross-industry impact). We could also model both aspects for a more realistic, though less tractable set up: $x_{z}=f\left(H_{z}^{x}, N_{z, j}, N_{z, i}, N_{i, l-z}\right)$. Imports into a specific industry will affect the development of goods in that industry differentially than innovation of goods in the economy in general. To ensure differential impact, we could attach different "weights" or "impact parameters" to $N_{z, i}$ (industry specific imported variety) versus $N_{i, l-2}$ (non-industry specific imported variety). 
For simplicity, assume that goods diversity is such that there is little overlap between intermediate inputs ${ }^{60}$ so that we can express $N$ as:

$$
N=N_{\text {hom } e}+\delta_{1} N_{\text {RIAparmer }}+\delta_{2} N_{\text {ROW }}
$$

where $0 \leq \delta_{1} \leq 1$ and $0 \leq \delta_{2} \leq 1$ are the parameter determining the degree of free access of the other RIA partners and ROW's differentiated intermediate exports to the Southern (home) country's market.

Formally, this market restriction can result from price differentials in intermediate imports from RIA members versus ROW. However, we abstract from the development of equilibrium price and wage conditions attached to this trade restriction. Suffice it to say that one modeling avenue would be to tack on a tariff (ad valorem) to the ROW prices, rendering their products less competitive. In other words, prices within and without the RIA will be different for intermediate inputs. By extension, the wages paid to the human capital involved in the industry producing them will not equalize across the two regions.

Anti-monde 1-Autarky: $\delta_{1}=\delta_{2}=0$

Assume: (i) $\sigma>1$,

(ii) No goods variety overlap (no redundancy effect),

(iii) $\delta_{1}=\delta_{2}=0$ in equation (6) - i.e. there is no trade and no exchange of information with ROW,

\footnotetext{
${ }^{60}$ This assumption reduces the role of the redundancy effect of regional integration and trade liberalization in growth analysis. In effect, it says that specialization has already occurred to a great degree and that opening the economy to the world or a subgroup of it (an RIA) will not have significant growth impact through the specialization/redundancy avenue. In other words, the competition effect between domestic intermediate input producers and new intermediate imports is minimized here, so that there is very little domestic industry rationalization in this specific market.
} 
(iv) The number of differentiated intermediate inputs in each of the two symmetric southern countries are limited to the nationally produced varieties in autarky. $\left(N_{\text {home }}=N_{\text {RIAparmer }} \leq N^{\text {row }}\right)$

Anti-monde 2 - Regional Trade: $\delta_{1} \geq 1, \delta_{2}=0$

Forming a South-South RIA will have the following results:

(1). It will double the pool of knowledge $\left(N=N_{\text {hom } e}+N_{\text {RIAparner }}\right)$ and the human capital working in the R\&D sector $\left(H^{x}=H_{\mathrm{hom} e}^{x}+H_{\text {RIAparner }}^{x}\right)^{61}$.

(2) The RIA formation lowers the cost of innovation from the vantagepoint of the home country and its RIA partner. Equations five applied to each member country will become:

$$
\pi_{x_{z}} \geq \frac{W^{H}}{N_{\text {hom } e}+N_{R I A p a r t n e r}}
$$

(3) The market enlargement will have two contradicting effects: improved profits prospects due to the enlarged market will be countered by more intense competition in it, so that the incentive to innovate is unchanged.(Walz, 1997:315; Rivera-Batiz \& Romer, 1991).

(4) (1) and (2) will lead to scale effects on output.

Furthermore, note that:

1. The rate of innovation will be four times that of each of the autarkic southern country rate because equation (4) is now:

$$
\dot{x}_{z}=\left(H_{z, \text { hom } e}^{x}+H_{z, \text { RlAparner }}^{x}\right)\left(N_{\text {hom } e}+N_{\text {RLAparner }}\right)
$$

and since the southern countries are symmetric:

$$
\dot{x}_{z}=\left(2 H_{z, \text { hom } e}^{x}\right)\left(2 N_{\text {hom } e}\right)
$$

\footnotetext{
${ }^{61}$ Refer to equations 3 and $6^{\prime}$ and recall that our model assumes that R\&D creates and produces intermediate inputs.
} 
2. In steady state, both the market enlargement effect and the redundancy effect (which we have assumed away here) are exhausted. The true dynamic growth effect is the scale effect that is prompted by the dynamics determining the rate of innovation at the domestic level ${ }^{62}$ in each member country.

3. While theoretically possible, we can not separate the scale effect from the market enlargement effect in our econometric exercise. Furthermore, we can not directly account for the human capital component affecting creation/production of intermediate inputs ${ }^{63}$.

\section{Anti-monde 3 - Open Regionalism: $\delta_{1}=1, \delta_{2} \leq 1$}

If we assume an open regionalism (hereafter OR) anti-monde, ascension to a RIA constrains the ROW's imports. Such constraints( e.g., , a positive tariff) on ROW exports to member countries can be quantified in our framework as $0 \leq \delta_{2} \leq 1$. The closer $\delta_{2}$ to 0 the more "closed" the regional arrangement to ROW, slowing the rate of innovation (scale effect) and the consequent growth in the RIA member countries growth rate by reducing the contributions of $N_{R O W}$ to equations (4) and (5-5') and (6').

This loss is enhanced by the two factors: the ROW is assumed to be larger than each of our southern countries do and have a comparative advantage in creation / production of intermediate inputs (recall that $N_{\text {hom } e}=N_{\text {RIAparner }} \leq N_{\text {ROW }}$ ). Puga and Venables (1997) and Ruhashyankiko (1997) both confirm that such an arrangement would have negative implications for the members of the RIA.

\footnotetext{
62 This has been shown by Grossman and Helpman (1991) and Rivera-Batiz and Romer (1991).

63 We have no industry level data on human capital
} 
As discussed in the literature, this model also suggests that open regionalism is a positive development compared to autarky and regionalism, since it allows for constrained entry of $N_{R O W}$. However, it is still an inferior choice to that of multilateral free trade. In fact, we think that the following proposition will hold true:

Proposition 1: given that (i) $\sigma>1$, (ii) $N_{\text {RIAparmer }} \leq N_{R O W}$. The larger the elasticity of substitution $\sigma$ and the smaller the ratio $0 \leq \frac{N_{\text {RIAparner }}}{N_{\text {ROW }}} \leq 1$, the smaller the impact of regional trade agreements on output growth compared to free trade.

In our empirical analysis, we do not have the opportunity to verify these scenarios independently. However, we note that both the Andean Group has engaged in multilateral liberalization while simultaneously reviving their respective RIA. It appears that we are in a situation akin to "open regionalism". In order to account for these simultaneous developments, our empirical exercise will control for the effects of the multilateral liberalization on industrial growth by introducing import variety series for non-RIA suppliers. These series are comparable to the ones calculated for RIA suppliers.

Empirically, we will rely on our three measures of intermediate import variety (discussed in main text) to capture the impact of the revival of the Andean Pact agreement on the industrial growth of each member country. Each of these measures in effect represents alternative empirical valuations of the $N_{\text {RIAparner }}$ and $N_{R O W}$ terms in equation ( $6^{\prime}$ ) and the subsequent analysis.

4. Based on the model and assumptions above, we expect: 
(a) each member to register an increase in the variety of imported goods from other RIA members from the RIA renewal date onward. We expect our three variety measures to capture this increase.

(b) we expect a positive and significant econometric correlation between these variety measures, represented by the generic $V A R$ term here, and industry level growth in equations (8) and (9) in the main document, reproduced here:

$$
\begin{aligned}
& d y_{i t}=\alpha_{t}+\gamma d x_{i t}+\lambda_{i} V A R+\left[d e_{i t}+d a_{i t}\right] \\
& d y_{i t}=\alpha_{t}+\gamma d x_{i t}+\kappa d x_{i}+\lambda V A R+\left[\xi d a_{t}+d u_{i t}\right]
\end{aligned}
$$

$\alpha_{t}$ is a constant. $x_{i t}=\alpha_{1 i t} l_{i t}+\alpha_{2 i t} k_{i t}+\alpha_{3 i t} m_{i t}{ }^{64} \cdot\left[d e_{i t}+d a_{i t}\right]$ in equation (8) and $\left[\xi d a_{i t}+d u_{i t}\right]$ in equation (9) are the error terms.

\section{Part II. Incorporating within and Cross-industry externality into the growth model.}

How would increased intermediate imports initiate a within and cross-industry scale response?

We view new varieties of intermediate imports as stores of foreign knowledge. We conceptualize that they have a strong industry specific knowledge accumulation component, and a more diffuse overall/general knowledge component. They affect the base of knowledge in the importing country in the following two complementary manners. At the cross-industry level, they enlarge the general, public base of knowledge, providing further incentives for innovation by reducing the cost of innovation/production of intermediate goods across all industries (nationally). Also, availability of new varieties of intermediate imports (competing with the

\footnotetext{
${ }^{64}$ by using the $d x_{i t}=\beta_{1 i t} d l_{i t}+\beta_{2 i t} d k_{i t}$ terminology and not directly estimating $\beta_{1 i t}$ and $\beta_{2 i t}$ coefficients we lose information about the changes in the contribution of labor and capital to production. One interesting extension of this exercise would be to perform this analysis with estimated beta coefficients.
} 
domestic supplying industries for instance) improves production efficiency and lowers input costs in industries using them for production of final goods ${ }^{65}$.

We abstract from arguing that within industry externalities are directly correlated to agglomeration effects resulting from the $\mathrm{RIA}^{66}$. We still attribute these externalities to the increased variety of intermediate inputs. For this we rely on the argument above, that there are potentially strong industry specific knowledge gains from imports introduced into that industry that are not replicated at the same level or intensity in other industries. Therefore, the dynamics of innovation and growth could be more potent at the industry level ${ }^{67}$.

We can also model a cross-effect between the RIA measures and within and crossindustry economies of scale in alternative ways.

In the first case, equations (8) and (9) will become ${ }^{68}$ :

$$
\begin{aligned}
& d y_{i t}=\alpha_{t}+\gamma d x_{i t}+\lambda V A R+\mu\left(V A R d x_{i t}\right)+\left[d e_{i t}+d a_{i t}\right] \\
& d y_{i t}=\alpha_{t}+\gamma d x_{i t}+\kappa d x_{t}+\lambda V A R+\mu\left(V A R d x_{i t}\right)+\omega\left(V A R d x_{t}\right)+ \\
& {\left[\xi d a_{t}+d u_{i t}\right]}
\end{aligned}
$$

For equations (10) and (11) we again interpret the coefficients $\mu$ and $\omega$ on the crosseffect terms as the impact of integration on economies of scales (both within and across-

${ }^{65}$ This is a level effect. The only way it will have long term growth impact is if the variety of imported goods is expanded continuously, thus "piling" level effects on top of each other at infinitum.

${ }^{66}$ We do not directly model the prerequisites for an agglomeration outcome since it requires cross-country factor movements (which we abstract from in our basic model in Appendix 1) and involves the more detailed analysis of centripetal and centrifugal economic forces between the integrating (see also Puga and Venables, 1997; Ruhashyankiko's 1997).

${ }^{67}$ Another way of modeling this dichotomy in the knowledge accumulation is to argue that the human capital is so specialized and productive in the set -up of the specific industry it is working in that it will "extract" more knowledge from its industry specific imports than the rest of the industries could. Alternatively, we could argue The human capital is differentiated by industry and therefore is less productive when having to absorb (or invent) in a general arena versus its own specific industry.

68 Harrison (1994) uses a similar set up for her analysis of the impact of trade liberalization on firm behavior in Cote d'Ivoire. 
industries) and by extension on growth. We expect both $\mu$ and $\omega$ to be positive and significant: regionalism (as proxied by increased variety of intermediate imports) enhances within industry. and external EOS and by extension growth.

An alternative approach is that of scaling the intermediate import flows into own industry inputs and cross-industry inputs series using country specific input-output tables.

We expect to observe a differentiated output response to these two series in equations (8)-(11).

A third and final approach would be to more specifically model regional partner's effects on home country within and cross-industry terms. One simplistic measure would be to use the sum of the trade (bilateral) weighted regional partner's within and cross-industry terms in equations (8)-(11) as proxy for the impact of the revival of the regional arrangements. 


\section{Appendix 3}

\section{Data}

The major concern throughout is compatibility of data across countries and the procedures applied to them to ensure the possibility of comparative analysis. For this reason, and serious weaknesses with data originating from national sources, we have relied on standardized international organization databases such as IMF, World Bank, UNIDO and Comtrade, using domestic sources as complementary sources when possible.

The analysis is based on 22 industries $^{69}$ for 1971-1994. The analysis concentrates on Bolivia, Ecuador and Colombia ${ }^{70}$. Venezuela lacked value added and intermediate inputs information and we could not perform a full analysis at present. The 3-digit data on the countries' industrial gross output production, gross fixed capital formation, number of employees, labor remuneration and intermediate inputs were obtained from UNIDO database. We calculate intermediate inputs as the difference between gross output and value added. Labor and intermediate input shares are calculated as shares of gross output and capital as the remainder. We used GDP deflators to create real series when necessary.

Capital stock is calculated using the modified version of Goldsmith perpetual inventory method:

$$
\mathrm{K}_{\mathrm{i}}(\mathrm{t})=\mathrm{I}_{\mathrm{i}}(\mathrm{t})+\left(1-\mathrm{d}_{\mathrm{i}}\right) \mathrm{I}_{\mathrm{i}}(\mathrm{t}-1)+\left(1-\mathrm{d}_{\mathrm{i}}\right)^{2} \mathrm{I}_{\mathrm{i}}(\mathrm{t}-2)+\ldots+\left(1-\mathrm{d}_{\mathrm{i}}\right)^{\mathrm{n}} \mathrm{K}_{\mathrm{i}}(\mathrm{t}-\mathrm{n})
$$

Investment series was deflated using each country's implicit invesment price deflator and some industry level data gaps were filled using the national gross domestic fixed investment growth rates. Both sets of data are from IMF statistics. A 10 percent discount rate was applied in the formula. This is typical in the literature (e.g. Caballero and Lyons) when actual depreciation rates are not available.

The import data is from COMTRADE UN database. It reports the value of bilateral imports in US dollars by industrial or product categories for 1970-1994. We use 3 digit ISIC and 4 digit SITC data series from this database. After calculating the supplier and variety series by industry categorization and supplying nation, we scale them using country specific input-output tables. This is to account for the impact of the imported intermediate inputs on own and other industries.

69 We discarded coal and petroleum $(354,353)$, leather products $(323)$, other chemical industries $(352)$, non-ferrous metals (372), and pottery, china, etc...(361) for either severe data deficiencies or severe and unexplainable changes in data values.

\footnotetext{
${ }^{70}$ Venezuela lacked value added and intermediate input information and a full analysis could not be performed at
} present. We had to discard a study of Peru early on because of significant missing data problems. 


\section{Appendix 4}

\section{Brief Review of Bolivia, Colombia and Ecuador Economic Facts}

\section{$\underline{\text { BOLIVIA }}$}

A small economy of some 6.5 , Bolivia's GDP per capita in 1993 was $\$ 821$. The distribution of wealth is highly unequal in this country still dominated by rural households. It has resumed a positive real rate GDP growth of 2.0-3.0 percent in 1993 and 1994.

It's major exports have historically been metals (tin, zinc,...), gas, and more recently nontraditional agricultural exports such as soybean. The majority of its imports are in capital goods and raw and intermediate inputs. Its major trade partners are the US, Japan, the EEC, Argentina, Brazil, Chile and the Andean Pact. This partner composition has not changed since the late 1970s. The Andean Pact has acquired an increasingly important role in Bolivia's trade in the 1990s. It constitutes an increased share of Bolivia's imports (from 4 percent in 1990 to 8 percent in 1994) and exports (from 6 percent in 1990 to 19 percent in 1994), closing on the only other major developing trade partner: Argentina. (IMF 1996 :table 57, statistical annex).

Historically, in the 1970s: The 1952 revolution established state capitalism and a methodology of government intervention that heavily influenced capital accumulation. The decade of the 70s was associated with a commodities, oil and gas boom, growth of capital inflow and indebtedness, but not much private investment took place during this period despite political stability and government encouragements. Much of the investment was undertaken by the government and many turned out to be inefficient industrial complexes. The economy grew at a rate of 4.5 to 5 percent per year during the decade.

The debt crisis exploded in the 1979 and the government attempted a crisis management and stabilization program consisting of devaluation and demand side repression in December 1979. The program was disrupted by a coup in 1980 and subsequent attempts at stabilization failed. In the early 1980 s the country experienced negative average annual growth rate of -4.0 percent and a major episode of hyperinflation during 1982-85.

Faced with severe economic crisis in the mid-80s, the government undertook far-reaching economic reforms to restructure and stabilize the economy. These reforms were deepened in 1989. The reforms included financial, public entreprise, mining sector, trade, price, exchange rate and capital market liberalization, tax structure and administration.

Of more direct interest with regards to imports: (IMF, 1996, pg 47).

The unilateral trade reform was implemented in 1985 and has been steadily pursued and deepened. While previously Bolivia had a low nominal average tariff of $12.1 \%$, effective protection was high on consumer durables and lowest on capital goods for agriculture due to tariff escalation. The reform introduced a trading system virtually free of restrictions. All quantitative restrictions on imports are removed except for public health and national security. In 1986 , a $20 \%$ uniform tariff was introduced to be decreased further by 1988 . The tariff system has not changed since 1990 with a low uniform tariff of 5 percent on capital goods and 10 percent on all other goods.

71 This information obtained from IMF's "Bolivia - recent economic developments -1996"; Francis Ng, (1994); WB, report no. 13067-BO, 1994; Juan Jose Echavarria "Trade flows in the Andean countries: Unilateral liberalization or regional preferences?", 1998, mimeo 
Export promotion led to a $10 \%$ duty draw back scheme in 1987 , reduced to $6 \%$ in 1990 and suspended in 1991 due to fiscal difficulties. In 1992, the government simplified export procedures guaranteeing freedom to export, access to international credit sources, import tax reimbursement to exporters, and convertability of national currency. The foreign exchange regime has also been reformed. The Boliviano has experienced a depreciation of $13 \%$ between 1990-1995

Stabilization did materialize and a fragile external balance and growth have resumed. The unexpectedly low and fragile growth is partially due to recovering - but as of yet still low of private savings rate (only 5.3 percent of GDP in 1993- WB, report no. 13067-BO, 1994:5). However, imports have been buoyant, reflecting increases in investment.

Bolivia has been pursuing greater trade rapport with the Mercosur and Andean Pact countries and LAIA.

The pattern of trade in the late 70s and early 80s: major exports were again concentrated in minerals and hydrocarbons, followed by agricultural products. At this time soybean was not an exported commodity yet. Merchandise imports: consumer goods constituted a relatively steady 18-22 percent of the total imports during this period. Raw materials and intermediate goods composed another $30-38 \%$ of the imports, the rest forming capital imports.

The direction of trade: During the late 1970s and early 1980s, Bolivia'smajor trade partners are the US, Japan (for imports but not exports), EEC, Argentina, Brazil and Chile. The Andean Pact ( members Peru and Colombia) does play a minor role as an export destination (up to 4.7 percent in 1980 , before decreasing to 2.3 percent in 1983) and as import source (a 3-5\% share of total Bolivian imports during 1977-1983)

Exports in the 1990s: the pattern of goods imports and exports is very similar to that of the early periods.

It's major exports are mining and carbohydrate products (tin, gold, silver, zinc, gas, petroleum...) and non-traditional agricultural exports. Metals accounted for a minimum of 40 percent of Bolivia's exports during 1990-1995. Soybean and soybean oil, timber, sugar and coffee represented a minimum of 30 percent of exports during this period. Gas exports has abruptly declined from a high of 25 percent of total exports in 1990 to below 10 percent in 1995. (IMF, 1996: 39).

Import structure in the 1990s:

Imports have risen steadily from US $\$ 962.7 \mathrm{M}$ in 1990 to US $\$ 1279 \mathrm{M}$ in 1994. Consumer goods constitute some 20 percent of the imports during the $1990 \mathrm{~s}$. Capital goods have held an approximate share of 40 percent. The share of raw materials and intermediate inputs in total imports has risen from 26 percent in 1990 to 38 percent in 1994. Among these, imports of industrial inputs have climbed from US $\$ 194.1 \mathrm{M}$ to US $\$ 355.2 \mathrm{M}$ (from 20 percent to 28 percent of total imports). (IMF, 1996: table 56, statistical appendix).

Manufacturing sector:

The manufacturing sector is a small contributor to the Bolivian economy. In 1994, it constituted 15\% of GDP. The production is mostly for domestic consumption, with food products, beverages and tobacco and textile accounting for almost two thirds of the total in 1995 (IMF, 1996:8). Another 25 percent corresponds to petroleum, coal and (and gas) derivations. The remaining industries contribute a very small share to output, with Woods products at $5.6 \%$, non-metallic minerals at $4.3 \%$ as highest contributors. 


\section{COLOMBIA}

Up to mid 1980s, Colombia espoused an import substitution development policy, protecting industry and agriculture via various trade tools, including high tariffs and quotas while promoting exports through tax, credit and exchange support measures.

In 1984, Colombia started reducing most import prohibitions, import licensing, and rationalizing its tariff structure. Between 1984-1989: import prohibitions fell from $16 \%$ of tariff lines to $1 \%$ and import licensing fell from $93 \%$ of all tariff lines to $60 \%$ and were granted virtually automatically. Later in the 1990 s, this share dropped to $2 \%$ of all tariff lines. In 1990 , a major trade liberalization process was initiated. At the time, the early dispersion of tariffs was very large: $0-200 \%$ in 25 steps, The range was first reduced to $0-62.7 \%$ and later to $0-20 \%$. Simple average tariff decreased substantially, from $61 \%$ in 1984 to $32.3 \%$ in 1988 and $11.5 \%$ in 1992 (with 5 levels). The trade reform also included reduction in export subsidies.

Between 1970-1995, Colombia GDP grew by an average of $4.5 \%$ per year. In the $1990 \mathrm{~s}$, it is expected that this average will be met and may be surpassed. Investment rate, capital formation, foreign direct investment have all grown during the $90 \mathrm{~s}$. One consequence has been the real foreign exchange rate has experienced a $20 \%$ steady appreciation between 1990-1995, affecting exports.

Generally, up to the mid-1980s, dependence on coffee exports and minerals (petroleum, coal, other minerals, etc...) were rather high. Between 1990-1994, however, industrial exports have grown from $20 \%$ of total exports to $32 \%$.

Import has also grown rapidly since 1986, increasing pace since the 1990 unilateral trade reforms (17\% of GDP in 1994). The good news is that some $45 \%$ of imports are capital goods, $40 \%$ are semi-manufactured and only $15 \%$ are consumer goods.

The revival of the Andean Pact started in 1989 and the countries achieved FTA in 1991. There are however, exceptions. For instance, tariff quotas was applied to a few products within the Andean Pact agreements. The automotive industry is a major benefactor of these trade constraints. Import quotas were applied to a few agricultural product.

One noteworthy result of this revival has been a substantial increase in trade with Venezuela (US 518M to US $2218 \mathrm{M}$ ) and Ecuador (from US $167 \mathrm{M}$ to US $696 \mathrm{M}$ ) a four-fold increase in both cases. In 1995, the Andean Pact composed 17.5\% of Colombian exports and $13.3 \%$ of its imports, much larger shares that in the pre-revival period. Note however, that the US, Canada and the EU are still very important trade partners to the country, composing approximately $60 \%$ of its exports and $58 \%$ of its imports.

\section{$\underline{\text { ECUADOR }} \underline{\underline{73}}$}

${ }^{72}$ This information obtained from Francis $\mathrm{Ng}$ (1994); IMF, "Colombia -Recent Economic Development- 1996"; and Sebastian Edwards, 1994, "Trade and Industrial Policy Reform in Latin America", NBER paper No. 4772; WTO "Trade Policy Review - Colombia, report by the government, 1996". Juan Jose Echavarria "Trade flows in the Andean countries: Unilateral liberalization or regional preferences?", 1998, mimeo

${ }^{73}$ This information obtained from World Bank report No. 15419-EC, Sebastian Edwards, 1994, "Trade and Industrial Policy Reform in Latin America", NBER paper No. 4772. Juan Jose Echavarria "Trade flows in the Andean countries: Unilateral liberalization or regional preferences?", 1998, mimeo; IMF's "Ecuador - Recent economic development - 1995" ; World Bank Report no. 8412-EC "Ecuador - Development of Manufacturing: policies, performance and outlook", 1990. 
Ecuador is a country of 11 millions, with two economic centers: Andean regions, relying mostly on government and domestic agricultural production (Quito), coastal regions, thriving on commerce. Before the discovery of oil in the Amazon, Ecuador was one of the poorest economies in Latin America.

The early 1970s was the advent of the petroleum era. Expansion of central government expenditures, services and borrowing from abroad. Incomes doubled Ecuadorans experienced a rapid improvement in living standards within the following decade. However, the decline of oil prices was followed by debt crisis in 1979-80.

Most of the 1980 s was spent undertaking recurrent stabilization efforts to control macroeconomic imbalances. Economic growth since the early 80s has averaged less than 3 percent per year, and the country has experienced a declining standard of living.

With an erroding standard of living, Ecuador has a GDP per capita of $\$ 1300$ in 1996 , and a highly skewed distribution of wealth. However, during the ' $80 \mathrm{~s}$, due to lack of political consensus and strong interest groups, the import-substitution development strategy was not changed, except for some financial and price liberalization in mid-decade and subsequent trade reform. These beliefs and resistance is still at work in the 1990s. It seems that the corner was finally turned in 1992 when the government started a restructuring program. Increased economic integration with the Andean Pact countries and economic recovery in other Latin American countries has help with the growth of Ecuador's regional exports.

The manufacturing sector constituted some $17 \%$ of GDP value added in 1970 . Over the past 25 years, this share has inched up 20 to $22 \%$ of GDP. However, the share of employment in manufacturing has hovered around $12 \%$ over the period, a reflection of a highly capital intensive manufacturing sector. This high capital intensity was fostered via investment subsidization policies and policies that rendered labor costly. However, the comparative advantage of the country is labor intensive and natural-resource-based goods.

For most of the period the production has gone to satisfy domestic demand. And the light traditional industries (food, tobacco, textiles, and wood) are still the dominant industries, constituting $70 \%$ in $1980 \mathrm{~s}$. The structure of the manufacturing sector moved towards more heavier industries. However, export of manufactured goods grew and became more diversified. By 1981, manufactured goods, accounting for $23 \%$ of exports, included processed foods, manufactured wood products, petroleum derivatives, metallic products, straw hats, electric appliances and some textiles and leather products.

A round of trade liberalization occured in the early 1970 s but was rolled back with the onset of the debt crisis in the early eighties and protectionist feelings it arose. The new round of multilateral liberalization took place almost simultaneously with the revival of the Andean Pact and has led to reduced tariff rates and removal of NTBs since the early 1990s. Concurrently, the currency has appreciated from 1990 to 1995. 


\section{Appendix 5}

\section{Andean Pact}

- Created in 1969 by Bolivia, Columbia, Chile, Ecuador, Peru and Venezuela. Chile left in 1976.

- Main objective was to enlarge their small domestic markets and promote industrial development through regional rather than domestic import substitution policies.

- Reaching their main objective involved:

1. regional industrial planning

2. trade liberalization

3. consessionary measures to less developed members (Bolivia and Ecuador)

- The Pact not very successful up to late 1980 s due to:

1. the blending of regional industrial planning and consessionary measures created enough exceptions as to minimize the impact of the RIA to a small impact on trade.

2. debt crisis of the $1980 \mathrm{~s}$.

- Renewal of the Pact in 1989 with the Declaration of Ica.

- Creation of free trade area in 1991, with the following goals:

1. total elimination of tariff and NTBs on internal trade

2. elimination of preferences for less developed member countries

3. eliminated the regional industrial planning goals.

4. expanded investment code granting national treatment to foreign investment.

- Results: strong impact on trade intensity. Total intra-group imports and exports shares have increased markedly.

From Foroutan, 1997. 
Graph 1: Andean Pact's Ratio of Regional to World Imports

(Industrial products, 1971-1995)

VENEZUELA: RATO OF REGONAL, TO THE REST OF THE WORLD INDUSTRIAL IMPORTS

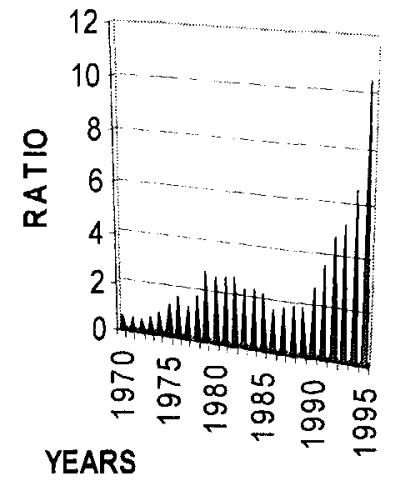

Graph 6: ECUADOR: RATIO OF REGIONAL TO THE REST OF THE WORLD INDUSTRIAL IMPORTS

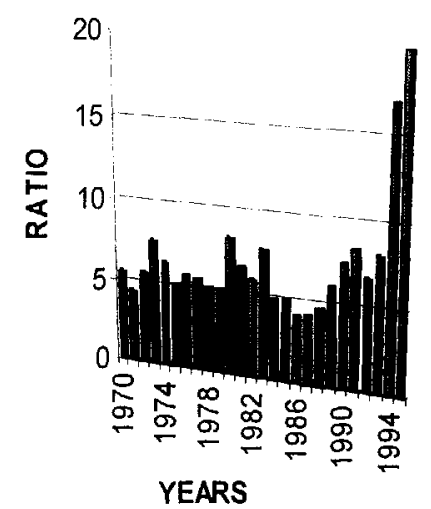

Graph 4: BOLIVIA: RATIO OF REGONAL TO REST OF THE WORLD INDUSTRIAL IMPORTS

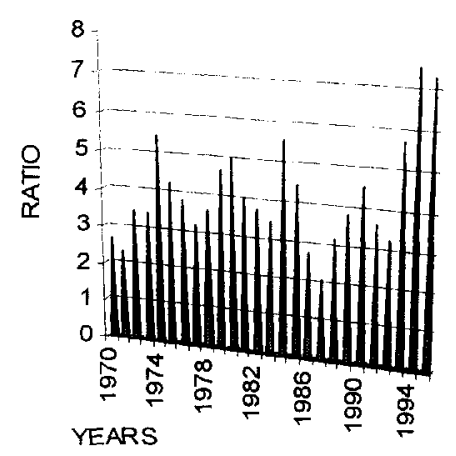

Graph 5: COLOMBIA: RATIO OF REGIONAL TO REST OF THE WORLD INDUSTRIAL IMPORTS

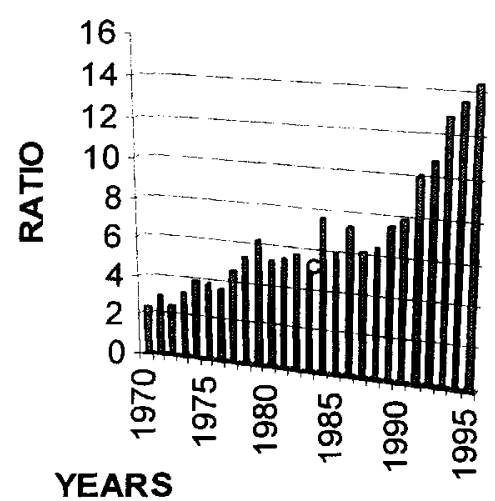




\section{Policy Research Working Paper Series}

\begin{tabular}{|c|c|c|c|c|}
\hline & Title & Author & Date & $\begin{array}{l}\text { Contact } \\
\text { for paper }\end{array}$ \\
\hline WPS2589 & $\begin{array}{l}\text { Implementing the Market Approach } \\
\text { to Enterprise Support: An Evaluation } \\
\text { of Ten Matching Grant Schemes }\end{array}$ & David A. Phillips & April 2001 & $\begin{array}{l}\text { S. Torres } \\
39012\end{array}$ \\
\hline WPS2590 & $\begin{array}{l}\text { Household Welfare and Poverty } \\
\text { Dynamics in Burkina Faso: Empirical } \\
\text { Evidence from Household Surveys }\end{array}$ & $\begin{array}{l}\text { Hippolyte Fofack } \\
\text { Célestin Monga } \\
\text { Hasan Tuluy }\end{array}$ & April 2001 & $\begin{array}{l}\text { N. Nouviale } \\
34514\end{array}$ \\
\hline WPS2591 & $\begin{array}{l}\text { Hirschmanian Themes of Social } \\
\text { Learning and Change }\end{array}$ & David Ellerman & April 2001 & $\begin{array}{l}\text { B. Mekuria } \\
82756\end{array}$ \\
\hline WPS2592 & $\begin{array}{l}\text { Management of Oil Windfalls in } \\
\text { Mexico: Historical Experience and } \\
\text { Policy Options for the Future }\end{array}$ & $\begin{array}{l}\text { Stephen Everhart } \\
\text { Robert Duval-Hernandez }\end{array}$ & April 2001 & $\begin{array}{l}\text { M. Kam-Cheong } \\
39618\end{array}$ \\
\hline WPS2593 & $\begin{array}{l}\text { Changing Trade Patterns after } \\
\text { Conflict Resolution in the South } \\
\text { Caucasus }\end{array}$ & Evgeny Polyakov & April 2001 & $\begin{array}{l}\text { Z. Nekaien-Nowrouz } \\
39057\end{array}$ \\
\hline WPS2594 & $\begin{array}{l}\text { Committing to Civil Service Reform: } \\
\text { The Performance of Pre-Shipment } \\
\text { Inspection under Different Institutional } \\
\text { Regimes }\end{array}$ & Noel Johnson & April 2001 & $\begin{array}{l}\text { L. Barbone } \\
32556\end{array}$ \\
\hline WPS2595 & $\begin{array}{l}\text { Unrestricted Market Access for } \\
\text { Sub-Saharan Africa: How Much Is It } \\
\text { Worth and Who Pays? }\end{array}$ & $\begin{array}{l}\text { Elena lanchovichina } \\
\text { Aaditya Mattoo } \\
\text { Marcelo Olarreaga }\end{array}$ & April 2001 & $\begin{array}{l}\text { L. Tabada } \\
36896\end{array}$ \\
\hline WPS2596 & $\begin{array}{l}\text { Shaping Future GATS Rules for } \\
\text { Trade in Services }\end{array}$ & Aaitya Mattoo & April 2001 & $\begin{array}{l}\text { L. Tabada } \\
36896\end{array}$ \\
\hline WPS2597 & $\begin{array}{l}\text { Measuring the Impact of Minimum } \\
\text { Wages: Evidence from Latin America }\end{array}$ & $\begin{array}{l}\text { William F. Maloney } \\
\text { Jairo Nuñez }\end{array}$ & April 2001 & $\begin{array}{l}\text { A. Pillay } \\
88046\end{array}$ \\
\hline WPS2598 & $\begin{array}{l}\text { Weightless Machines and Costless } \\
\text { Knowledge: An Empirical Analysis of } \\
\text { Trade and Technology Diffusion }\end{array}$ & $\begin{array}{l}\text { Giorgio Barba Navaretti } \\
\text { Isidro Soloaga }\end{array}$ & May 2001 & $\begin{array}{l}\text { L. Tabada } \\
36896\end{array}$ \\
\hline WPS2599 & $\begin{array}{l}\text { State Ownership and Labor } \\
\text { Redundancy: Estimates Based on } \\
\text { Enterprise-Level Data from Vietnam }\end{array}$ & $\begin{array}{l}\text { Patrick Belser } \\
\text { Martín Rama }\end{array}$ & May 2001 & $\begin{array}{l}\text { H. Sladovich } \\
37698\end{array}$ \\
\hline WPS2600 & $\begin{array}{l}\text { Rent-Sharing, Hold-Up, and } \\
\text { Manufacturing Wages in Côte d' Ivoire }\end{array}$ & $\begin{array}{l}\text { Jean-Paul Azam } \\
\text { Catherine Ris }\end{array}$ & May 2001 & $\begin{array}{l}\text { H. Sladovich } \\
37698\end{array}$ \\
\hline WPS2601 & $\begin{array}{l}\text { The WTO Agreement and } \\
\text { Telecommunications Policy Reform }\end{array}$ & $\begin{array}{l}\text { Peter Cowhey } \\
\text { Mikhail M. Klimenko }\end{array}$ & May 2001 & $\begin{array}{l}\text { L. Tabada } \\
36896\end{array}$ \\
\hline
\end{tabular}


Policy Research Working Paper Series

Title

WPS2602 Sugar Policy and Reform

WPS2603 How the Quality of Institutions Affects Technological Deepening

in Developing Countries

WPS2604 Eliminating Excessive Tariffs on Exports of Least Developed Countries

WPS2605 The Macroeconomic Impact of Bank Bank Capital Requirements in Emerging Economies: Past Evidence to Assess the Future

WPS2606 Exchange Rate Risk Management: Evidence from East Asia

WPS2607 The Economical Control of Infectious Disease

WPS2608 Financial Development and International Trade: Is There a Link?

WPS2609 Financial Dependence and International Trade

WPS2610 Crisis and Contagion in East Asia: Nine Lessons

WPS2611 Trade and Production Fragmentation: Central European Economies in European Union Networks of Production and Marketing

WPS2612 Contractual Savings, Capital Markets, and Firms' Financing Choices

WPS2613 Foreign Direct Investment and Poverty Reduction
Author

Donald F. Larson

Brent Borrell

George R. G. Clarke

Bernard Hoekman

Francis $\mathrm{Ng}$

Marcelo Olarreaga

Maria Concetta Chiuri

Giovanni Ferri

Giovanni Majnoni

George Allayannis

Gregory W. Brown

Leora F. Klapper

Mark Gersovitz

Jeffrey S. Hammer

Thorsten Beck

Thorsten Beck

Masahiro Kawai

Richard Newfarmer

Sergio Schmukler

Bartlojiej Kaminski

Francis $\mathrm{Ng}$

Gregorio Impavido Alberto R. Musalem Thierry Tressle

Michael Klein

Carl Aaron

Bita Hadjimichael
Date

May 2001

May 2001

May 2001

May 2001

May 2001

May 2001

May 2001

May 2001

June 2001

June 2001

June 2001

P. Braxton 32720

June 200

Z. Fanai 33605

Contact for paper

P. Kokila 33716

P. Sintim-Aboagye 38526

L. Tabada 36896

E. Mekhova 85984

A. Yaptenco 31823

H. Sladovich 37698

A. Yaptenco 38526

A. Yaptenco 38526

E. Khine 37471

L. Tabada 36896 